\title{
Translation
}

\section{Otto von Gierke: The Social Role of Private Law*}

Translated, with an introduction, by Ewan McGaughey. ${ }^{*}$

* Originally published in German as Die soziale Aufgabe des Privatrechts (1889)

** Lecturer in Private Law, King's College, London. Research Associate, University of Cambridge, Centre for Business Research. Please email ewan.mcgaughey@kcl.ac.uk for comment and discussion. I am very grateful to the organizers and participants of the IVR 2015 Conference for input. All errors in this case are mine: A "private" not a social phenomenon here. 


\section{A. Introduction: A Social Law Beyond Public v. Private}

Otto von Gierke wrote The Social Role of Private Law (Die soziale Aufgabe des Privatrechts) in an age of extraordinary belief in progress and pride. In 1889, the Eiffel Tower was inaugurated, Britain's Royal Navy was required by law to outdo its next two rivals combined, ${ }^{1}$ and Germany was forging a massive new Civil Code (Bürgerliches Gesetzbuch). Within a year, Kaiser Wilhelm II had dismissed Otto von Bismarck: The old Iron Chancellor, who had unified a 'Second' Reich but no longer moved fast enough to secure a "place in the sun." Ages of great confidence often see codes of law: Justinian's Corpus Juris Civilis in a reunited West and Eastern Rome; the Code Civil of the Napoleonic Empire; the Penal, Contract or Trust Acts from 1860 to 1882 across the British Empire; and the US Code of 1926. A desire for legal certainty sometimes drives reform, but rarely as much a desire to display superiority. The flicker of history must be made to seem timeless, like laws seem in printed word.

Gierke was born in Szczecin, Poland-then Stettin in Prussia-in 1841. He worked and lived in Berlin from 1887 to 1921. As well as a three-volume commentary on German Private Law, his magnum opus was a four-volume treatise called Genossenschaftsrecht. This translates as the Law of Cooperatives or possibly Fellowship, ${ }^{2}$ but was essentially a history of the German Law of Associations and Corporations, infused with Gierke's ideals of mutual trust. A decorated professor, Gierke sought to re-narrate the social life of law, back to the day when Tacitus recorded the habits of German tribes. This project led Gierke to reject a reimposition of supposed "Roman law" stricture by codification. He was a companion of Frederick Maitland in Cambridge, who translated part of Gierke's work in 1900 and influenced generations of English-speaking pluralists. Gierke was embraced by progressive American scholars and was awarded a doctorate at Harvard in 1909. But despite his progressive, internationalist reception, Gierke himself was a conservative and a nationalist. He believed in Germanness, the Reich, and after its ruin, the Deutschnationale Volkspartei. ${ }^{3}$ Yet for Gierke the priceless objective, the thing he sought to conserve, and the bond he craved for Germany, was the pride of a more social law.

The core argument in The Social Role of Private Law was that law is unified and animated by social groups. Everyone (like that term itself) "lives simultaneously as oneself and as one of a kind." Had Gierke been American, his motto might have been E Pluribus Unum. As one organism, Gierke believed all law must pursue a common goal. The Roman abstractions of public and private, person, property, or contract, were unneeded. They were also unwanted.

\footnotetext{
${ }^{1}$ Naval Defence Act 1889 (Gr. Brit).

2 See F.W. Maitland, Translator's Introduction, in PoliticAL THeORIES OF THE MIDDLE AGE xxvi (1900) (translating O. Gierke, Das Deutsche Genossenschaftsrecht (1881) vol 3, §11).

${ }^{3}$ See O. Gierke, Einige Wünsche an die Deutschnationale Volkspartel [SOme Wishes to the German People's Party] (1920); See also O. Gierke, A FeW Suggestions for the German NATIONAL People's Party. Gierke's daughter, Anna von Gierke, became a Member of Parliament (Abgeordnete) for the DNVP.
} 
If property were seen as a relation between persons and things, it would obscure the irresponsible abuse of rights toward other people. The "principle of "no rights without duties, "' for Gierke, was "the internal bond of our Germanic view." ${ }^{4}$ If contracts were seen as mere relations among individuals then they obscured meaningful imbalances of power between different people. To Gierke, freedom of contract risked becoming a "fearsome weapon in the fist of the strong, a blunted tool in the clutch of the weak." 5 If public and private spheres were abstracted, this obscured what was surely the true aim, that law should "build and secure the life of the community as a whole" to uphold "each person's unique and immortal worth." ${ }^{\text {It }}$ was misguided to relegate "social-political acts" to "specialist" statutes, leaving intact the supposed private law framework "like an abstract stencil, romantic, individualistic, ossified in obsolete dogmatism." Ultimately, Gierke implies, a public-private division is dishonest. It misrepresents how law truly works. "Public law should," wrote Gierke, "be blown a scent of natural law freedom and our private law must absorb a drop of socialist ointment."7

Gierke's criticism was aimed directly at the Draft Civil Code, as it stood in 1889. The Social Role of Private Law argued for its revision. ${ }^{8}$ But the substance of Gierke's critique could equally have been aimed at the United States, Britain, or any industrial society. ${ }^{9}$ Gierke

${ }^{4}$ O. Gierke, The Social Role of Private LaW 20 (1889).

${ }^{5} / d$. at 28

${ }^{6} / d$. at 2,11

${ }^{7}$ Id. at 13

8 See also, O Gierke, Der EntWurf eines bürgerlichen Gesetzbuches und das deutsche ReCht [The Draft of a CiVIL Code AND GERMAN LAW] (1888) 12(3) JAHRBÜCHER FÜR GESETZGEBUNG, VERWALTUNG UND VolKSWIRTSCHAFt 57-119, 12(4) JGVV 109-195, and (1889) 13(1) JVWW 183-322. A fully revised Draft Civil Code was released in 1895, passing and in force in 1900.

${ }^{9}$ See also, O Gierke, 1 Deutsches PRIVATRECHT $\$ 4,27$ (1895):

$$
\begin{aligned}
& \text { Anders verhält es sich mit der heutigen Unterscheidung von } \\
& \text { Privatrecht und öffentlichem Recht. Nach germanischer und moderner } \\
& \text { Rechtsanschauung erschöpft sich die Gesellschaft nicht im Staat, } \\
& \text { sondern kommt zugleich in einer Fülle andersgearteter } \\
& \text { Gemeinschaften mit eignem Lebenszweck zur Erscheinung: in der } \\
& \text { Familie, in der Kirche, in der Gemeinde, in der Genossenschaft, in der } \\
& \text { internationalen Gemeinschaft. Es giebt also unendlich viel Sozialrecht, } \\
& \text { das nicht Staatsrecht ist. Der Staat aber als souveräner Verband weist } \\
& \text { diesem Sozialrecht je nach dem Werthe, den er dem dadurch } \\
& \text { geregelten Gemeinleben für sein eignes Leben beimißt, eine ungleiche } \\
& \text { Stellung zu, indem er es zum Theil mit gleichen oder ähnlichen } \\
& \text { Machtmitteln wie das Staatsrecht ausrüstet, zum andern Theil } \\
& \text { dagegen mit keiner höheren Autorität als das Individualrecht } \\
& \text { bekleidet. So ergiebt sich eine rein positive Grenzziehung zwischen }
\end{aligned}
$$


would have been well aware of the Civil Rights Cases, where a US Supreme Court majority held the Civil Rights Act of 1875 was "unconstitutional." This had entitled everyone to access accommodation, public transport, and theatres regardless of race or color. But Justice Bradley for the majority reasoned that the Fourteenth Amendment's protection of every person's "life, liberty, or property" according to "due process of law" did "not authorize Congress to create a code of municipal law for the regulation of private rights," as supposedly distinct from "state" laws. ${ }^{10}$ Seemingly rolled into one salient case were all the consequences of a public-private divide. State bodies were sufficiently "public" to be regulated: "Private" bodies could not be. In his timeless dissent, Justice Harlan would have held the Civil Rights Act of 1875 valid because without law people were left "practically at the mercy of corporations and individuals wielding power under public authority." Denial of rights against "private parties" meant public courts enforcing dispossession, like a new age of Enclosure Acts. This binary divide of public and private law was used to advance an indefensible hierarchy, not unravelled until the Civil Rights Act of 1964.

Defenders today of a public-private divide scarcely endorse the tremendous injustices wrought by the Jim Crow and ensuing Lochner eras. An analytical abstraction need not be abused, as it was back then. But what positive purpose could it serve? In Lochner v New York, ${ }^{11}$ the Supreme Court's majority held that New York's Bakeshop Act of 1896, limiting bakers' working week to 60 hours, or 10 hours a day, violated the Fourteenth Amendment's due process clause. "It is a question," said Justice Peckham, "of which of two powers or rights shall prevail,- the power of the state to legislate or the right of the individual to liberty of person and freedom of contract." The "real object and purpose" of the law was "to regulate the hours of labor between the master and his employees... in a private business." In one

Privatrecht und öffentlichem Recht, die das Sozialrecht in der Mitte durchschneidet.

${ }^{10}$ United States v. Stanley, 109 U.S. 3 (1883). U.S. CoNST. amend. XIV, passed after the US Civil War (1860-1865) and Abraham Lincoln's delivery of the Emancipation Proclamation on January 1, 1863 to end slavery, reads:

No State shall make or enforce any law which shall abridge the privileges or immunities of citizens of the United States; nor shall any State deprive any person of life, liberty, or property, without due process of law; nor deny to any person within its jurisdiction the equal protection of the laws.

${ }^{11}$ Lochner v. New York, 198 U.S. 45, 64 (1908). Justice Beckman explains:

It seems to us that the real object and purpose were simply to regulate the hours of labor between the master and his employees (all being men sui juris) in a private business, not dangerous in any degree to morals or in any real and substantial degree to the health of the employees. Under such circumstances, the freedom of master and employee to contract with each other in relation to their employment, and in defining the same, cannot be prohibited or interfered with without violating the Federal Constitution. 
sphere stood the public, or the government, and in the other sphere resided the private, or the market. In his dissent, Justice Holmes urged that "a Constitution is not intended to embody a particular economic theory, whether of paternalism and the organic relation of the citizen to the state or of laissez faire. It is made for people of fundamentally differing views." This said, Holmes shared an "organic relation" theory ${ }^{12}$ that Holmes owed it to Gierke.

Why did a German social lawyer enter the most famous dissent in US judicial history? In 1900, at the University of Cambridge, Frederick W. Maitland, had published a partial translation of Gierke's work, on Political Theories of the Middle Ages. ${ }^{13}$ Holmes read it. Like history being a "seamless web," ${ }^{14}$ the law being a social unity did not mean internal classifications were wrong. Public and private, person, property and obligation could be one option. But what objectives did a given classification advance? Maitland, a scholar of equity, was obviously partial to a view that some principles cut across those Roman classes, and that those classes could not account for all principles of law. And if ever principle were lacking in law, it was evident in the House of Lords' notorious labor suppression cases, starting the following year (Taff Vale, Quinn v Leathem, South Wales Miners). They relied on the sanctity of contract to suppress trade unions. ${ }^{15}$ Their Lordships' law gave employers implied rights to unilaterally alter the consideration of a bargain, dismiss workers, and cause economic loss. But workers had no right to withdraw their labor in a good faith trade dispute. They would pay damages to the employer. In Quinn in particular, Lord Lindley transformed the employer's business or "liberty to deal with other persons" into a type of property right, a "liberty or right," with a "general duty on every one not to prevent the free exercise of this liberty." ${ }^{16}$ Across the Atlantic, Wesley Hohfeld famously derided the "question begging" and "seductive influence" of that misused word "right" in his pathbreaking analysis of fundamental legal concepts. ${ }^{17}$ Fortunately, and unlike Congress, Parliament could overturn the UK courts. As Sidney and Beatrice Webb recounted, all trade unions, "every society,

\footnotetext{
${ }^{12}$ Mount Vernon Cotton Co. v. Ala. Power Co, 240 U.S. 30, 32 (1916).

${ }^{13}$ O Gierke, Political Theories of the Middle Ages (F.W. Maitland trans., 1900). This came from 3 Das deutsche Genossenschaftsrecht (1881) §11, Die publicistischen Lehren des Mittelalters. See also, F.W. MAITLAND, ToWNSHIP AND BOROUGH 30-31 (1898).

${ }^{14}$ F.W. Maitland, A Prologue to a History of English Law, 14 LQR 13 (1898), "Such is the unity of all history that any one who endeavours to tell a piece of it must feel that his first sentence tears a seamless web."

${ }^{15}$ Taff Vale Ry. Co. v. Amalgamated Soc'y of Ry. Servants [1901] UKHL 1, Quinn v. Leathem [1901] UKHL 2, [1901] AC 495 (HL) 534, S. Wales Miners' Fed'n. v. Glamorgan Coal Co. [1905] AC 239.

${ }^{16}$ Quinn v. Leathem [1901] UKHL 2, [1901] AC 495 (HL) 534.

17 W.N. Hohfeld, Some Fundamental Legal Conceptions as Applied in Judicial Reasoning, 23 YALE L. J. 16, 42-43 (1913).
} 
great and small, and every branch rallied in defense of its right to exist." ${ }^{18}$ They won and affirmed the human right to collective action and fair wages, above business rights of property or contract. ${ }^{19}$

How did Roman law classifications fare in Gierke's Germany? The Prussian state, along with its Civil Code (Bürgerliches Gesetzbuch), was soon confronted with the ruin of war. In Weimar's struggling democracy, Gierke was no political follower of social democrats. But their intellectual leader, Hugo Sinzheimer, certainly followed Gierke. Sinzheimer spoke of the "undivided unity of the law," and he urged that the "boundaries in which the dominant legal teachings proceeds from public and private law are intrinsically non-existent." ${ }^{20} \mathrm{His}$ greatest achievement was in the Weimar Constitution of 1919. Article 153 recalled that "Property carries responsibility" (Eigentum verpflichtet, still the shortest constitutional sentence). Article 165 required workers would have rights to cooperate with management "in the entire field of the economic development." Democracy's advance in politics meant recognizing the individual's voice in the affairs of the state. Democracy's advance in economics meant social participation in the terms of corporate or individual trade. This was neither an irresponsible populous undermining state integrity, nor public power interfering in private liberty. As true defenders of liberty knew, "trade is a social act." ${ }^{21}$

Gierke passed away in 1921, with Weimar's fifth Chancellor in three years of the "AngloSaxon peace." ${ }^{22}$ Gierke could not be consoled about the Second Reich's military defeat. He attributed it to a supposed moral collapse of the German people. Ironically, and tragically, his ideas may in the long term have done more to win the peace for Germany's former rivals than at home. The intellectual lineage of Lochner's opponents were the American legal realists. Patient and relentless, their work demonstrated, in the face of Supreme Court jurisprudence, why all private rights - property, contract, whatever-had to be understood as a question for public institutions. ${ }^{23}$ This analysis had inevitably acquired a normative

\footnotetext{
18 S. WeBB \& B. WebB, The History of TRADE Unionism 604 (1920).

19 Trade Disputes Act (1906).

${ }^{20}$ See H Sinzheimer, Ein Arbeitstarifgesetz 21 (1916), speaking of the "undivided unity of the law." ("ungetrennten Einheit des Rechts"). "The boundaries in which the dominant legal teachings proceeds from public and private law are intrinsically non-existent." ("Die Schranken, die die herrschende Rechtslehre zwischen öffentlichem Recht und Privatrecht aufführt [sind] innerlich nicht vorhanden.")

21 J.S. MILL, ON LIBERTY ch 5 (1859).

${ }^{22}$ K. Malowitz, "' . . . Wiederbesinnung auf unser Germanentum . . . 'Otto von Gierke und der Kampf um die Deutung der Weimarer Republik und ihre Verfassung," [Re-thinking of our Germanism. , , 'Otto von Gierke and the struggle for the interpretation of the Weimar Republic and its constitution] in Verfassungsidee und Verfassungspolitik 53, 55 (M. Llanque \& D. Schulz eds., 2015).

${ }^{23}$ E.g. R. Pound, Liberty of Contract 18 YALE L. J. 454 (1909). R. Hale, Coercion and Distribution in a Supposedly NonCoercive State 38 POL. SCI. Q. 472 (1923). M. Cohen, Property and Sovereignty 13 CoRnELL L. Q. 8 (1927). R Hale, Force and the State: A Comparison of "Political" and "Economic" Compulsion 35 CLR 149 (1935). L.L. Fuller \& WR Perdue,
} 
content. They threatened democracy and prosperity. The Wall Street Crash came in 1929, a result of failure to ensure adequate disclosure of company securities information in public markets, where the retirement savings of millions of Americans were invested. ${ }^{24}$ Why did Americans invest in the stock market so much when compared to the British or Germans? Precisely because US courts had declared unconstitutional virtually all attempts to create public pensions, labor rights, and social security. ${ }^{25}$ The law had mandated a captive market for the promoters, speculators, and bankrupt banks. ${ }^{26}$

The crash and the fatal decision to lockdown international investment ${ }^{27}$ may have sent the global economy into free fall. Yet in the US, the values of a more social law ascended. A.A. Berle, the author of President Roosevelt's defining statement of policy, introduced the idea of a second bill of economic and social rights. All of society, and not just in government politics, did have and should have a constitution framed by law. ${ }^{28}$ It was time to explicitly recognize that there would be a new bill of social and economic rights. Divisions of public and private, state and contract, were finally rejected by the US Supreme Court. ${ }^{29}$ There was to be no a priori right of any person or business to demand the help of taxpayer funded courts on terms society thought unjust. ${ }^{30}$ The movement's crowning achievement, the

The Reliance Interest in Contract Damages 46 YALE L. J. 52 (1936). R. Hale, Bargaining, Duress and Economic Liberty (1943) 43 Colum. L. R. 625.

${ }^{24}$ A.A. Berle \& G.C. Means, The Modern Corporation and Private Property Book III (1932).

${ }^{25}$ E.g. State Bd. of Control v. Buckstegge, 158 Pac 837 (1916); R.R. Ret. Bd. v Alton R.R. Co., 295 U.S. 330 (1935).

${ }^{26}$ E. McGaughey, Participation in Corporate Governance ch. 6(3) (2014).

${ }^{27}$ Smoot-Hawley Tariff Act of 1930.

${ }^{28}$ F.D. Roosevelt, Campaign Address on Progressive Government at the Commonwealth Club in San Francisco, California (1932). This was written by Berle. See R. Eden, On the Origins of the Regime of Pragmatic Liberalism: John Dewey, Adolf A. Berle, and FDR's Commonwealth Club Address of 19327 StUdies IN AMERICAN Political DeVELOPMENT 74, n.109 (1993). See also, State of the Union Address (Jan. 11, 1944) (on a "Second Bill of Rights").

${ }^{29}$ E.g. West Coast Hotel Co v. Parrish, 300 U.S. 379 (1937); Helvering v. Davis, 301 U.S. 619 (1937)

${ }^{30}$ Cf. Shelley v. Kraemer, 334 U.S. 1, 19 (1948), per Chief Justice Vinson:

These are not cases, as has been suggested, in which the States have merely abstained from action, leaving private individuals free to impose such discriminations as they see fit. Rather, these are cases in which the States have made available to such individuals the full coercive power of government to deny to petitioners, on the grounds of race or color, the enjoyment of property rights in premises which petitioners are willing and financially able to acquire and which the grantors are willing to sell. 
Universal Declaration of Human Rights 1948, made this clear. Private rights of property or contract might be important, but so were rights to fair wages, social security, and democracy. ${ }^{31}$ In a world where human rights-like freedom of association, just and favorable remuneration, and equal treatment-bound states, corporations and employers alike, the old purpose of dividing public from private, the state from the individual, would be gone in all but name.

The peak for theories of social law and justice in the English-speaking world was reached through the 1950s and 1960s. ${ }^{32}$ A unitary model of contract law gave way to a law of contracts. ${ }^{33}$ There were general principles of contract formation, vitiation, or termination. But surrounding those were a cluster of specific contract types, reflecting special duties, and rights-for employment, consumers, tenancies-like planets orbiting a sun. A singular model of property gave way to a distinction between property used for production and consumption, a difference between business corporations or personal possessions. ${ }^{34}$ This was gradually seen in everything from rules on priority in insolvency, to protection of human rights. ${ }^{35}$ Personhood itself could hardly maintain a fictional equality: human beings, corporations, and states differ in their constitution and power. ${ }^{36}$

See also, J.S. MILL, PRINCIPLES OF PolitiCAL ECONOMY Book V, ch 1, §2 (1848), "governments do not limit their concern with contracts to a simple enforcement. They take upon themselves to determine what contracts are fit to be enforced."

${ }^{31}$ UDHR 1948 arts 21-23.

${ }^{32}$ See O. Kahn-Freund, Hugo Sinzheimer, in Labour LaW AND Poltics IN THe WeIMAR RePUblic 103 (1981):

\begin{abstract}
The technique of bourgeois society and its law is to cover social facts and factors of social existence with abstractions: property, contract, legal person. All these abstractions contain within them socially opposed and contradictory phenomena: property used for production and property used for consumption, agreements between equal parties and agreements between unequal parties, capitalist and worker. Through abstraction it is possible to extend legal rules, which are appropriate to the social phenomenon for which they were originally developed, to other social phenomena, thereby concealing the exercise of social power behind a veil of law.
\end{abstract}

${ }^{33}$ F. Kessler, Contracts of Adhesion - Some Thoughts About Freedom of Contract, 43 CoLUM. L. R. 629, 634 (1943).

${ }^{34}$ A.A. Berle, Property, Production and Revolution, 65 Colum. L. R. 1 (1965). See also Bundesverfassungsgericht [BverfGE] [Federal Constitutional Court], Mar. 1, 1979, 50 BVerfGE 290, n.315 (Mitbestimmungsgesetz).

35 Insolvency Act 1986, ss 175-176A (on employee, and unsecured creditor priority over floating charge holders in insolvency). ECHR Prot. 1, Art. 1 (on the human right to property: That is "Possessions").

${ }^{36}$ Reflected by Lord Denning MR, Littlewoods Mail Order Stores v. Inland Revenue Commissioners [1969] 1 WLR 1241. 
As law's functions became more social, the development of a modern regulatory state meant legal subjects flourished over a public-private divide: Labor law, tenancy law, competition law, corporate governance, consumer law, or, indeed, the law of cyberspace. ${ }^{37}$ The total breakdown of the old theories was most evident in corporate law. The corporation has been argued to be a "concession of the state," 38 a "nexus of contracts," 39 an entity with "proprietary foundations," ${ }^{40}$ and of course a "person." ${ }^{41}$ It is literally conceptualized as being public law, private law, an obligation, property, and person. In other words, the public and private divide had become utterly useless for explaining the most socially significant phenomena of modern times. The most poignant question, still to be fully articulated, is how people's rights should be constituted across all different types of human association.

Since the 1970s there is little doubt that a public and private divide ascended in many ways again. Several reasons for this, crossing economics, politics, and law, are clear. For one, an unusually influential Austrian lawyer, turned economic theorist, named Friedrich von Hayek, asserted a public-private divide as fundamental to his understanding of why social justice must be a "mirage." Social justice was, said Hayek, an "outlet for moral emotion." ${ }^{42}$ The political shifts from the 1980s in the UK and US went some way to imposing that theory on reality. ${ }^{43}$ According to Hayek, private law serves a function of corrective justice, simply creating "rules of just conduct" that were "end-independent," and therefore not distributive. 44 It makes markets a "spontaneous order." ${ }^{45}$ Apparently nobody directs markets, and because "justice" requires someone to be responsible for it, it apparently followed that social justice claims - which affect markets-have no "meaning or content

\footnotetext{
${ }^{37}$ F.H. Easterbrook, Cyberspace and the Law of the Horse, UNIVERSITY OF CHICAGO LEGAL FORUM. 207, 208 (1996).

${ }^{38}$ E.g. Trustees of Dartmouth College v. Woodward, 17 U.S. 518, 636-638 (1819).

${ }^{39}$ See E. McGaughey, Ideals of the Corporation and the Nexus of Contracts, 78(6) MoD. L. R. 1057 (2015). See also F. Kessler, Book Review: Wirtschaftsführertum und Vertragsethik im Neuen Aktienrecht [Business Leadership and Contract Ethics in New Company Law], 83 U. PA. L. R. 393, 394 (1935). F. Easterbrook \& D. Fischel, The Corporate Contract, 89 Colum. L. R. 1416 (1989).

${ }^{40}$ E.g. J. Armour \& M.J. Whincop, The Proprietary Foundations of Corporate Law, 27(3) OXFoRd J. LegaL StUD. 429 (2007). See also H. Hansmann \& R. Kraakman, The Essential Role of Organizational Law, 110 YALE L. J. 387 (2000).

${ }^{41}$ Salomon v. A. Salomon \& Co. Ltd. UKHL 1 [1896].

${ }^{42}$ F. HAYEK, LAW, 2 LEGISLATION AND LIBERTY 227-232 (1973).

${ }^{43}$ Cf. F.A. Hayek, Why I am not a Conservative, in THE CONSTITUTION OF LIBERTY (1960). Thatcher declared the book to be "what we believe."

${ }^{44}$ HAYEK, supra note 42, at 197, 201, 269 (1973).

${ }^{45} / d$. at 230.
} 
whatever." ${ }^{46}$ Views like this began a new generation of theory, culminating in the "Washington consensus."

Matters differed in civil law jurisdictions. In Germany, the court system had to some extent maintained the theoretical divide as practical reality, without the implications for government and markets. The same was true in France. But regardless of courts, many legal scholars, certainly without any political aim, desired a clarity and structure of legal classification. "Contextual" subjects that did not fit into public and private, person, property, and obligation, were not necessarily wrong. But they were said to be inferior at accounting for the law as a whole. ${ }^{47}$ The currency of real legal scholarship, it was said, was "concepts" not contexts. The uncomfortable fact that "the state" and "the individual," public and private, were contextual topics - making any subcategory contextual too-could quietly be ignored. So could the incessant criticism of a public, private divide, ${ }^{48}$ because of one hard truth. The criticism of a theory is not an alternative. Only a better theory beats a bad one.

This leads to a central question for today's legal scholarship. What if Gierke, Holmes, and Maitland, Sinzheimer, the Webbs, and Berle were right? If the public, private divide is wrong, what could go in its place? If the law is not to be divided, but united, how should it best be explained? Is any replacement necessary, or can law get comfortably by with contextual topics for each area of life, like the shifting names of government Ministries? What could be the starting point for a different classification? Could it be an analysis of power that common law sought to contain, or principles of equity that the Chancery once developed? Could the law benefit from theories of economic, social, or political science on the structure and relationships in human associations? Or should a public-private divide be left alone, but continue its internal transformation, and be supplemented in light of new social change? These are questions for another place. Maybe they cannot be resolved. But if there will be a resolution, help is found half the way by understanding The Social Role of Private Law.

\footnotetext{
${ }^{46} / d$. at $227,231-32$. At 242 , he exclaims there was "no end to the violence that will be done to language" to get social justice and it even led to the "expression 'global justice!"

47 P. BIRKS, INTROdUCtION TO THE LAW OF RESTITUTION 73 (1984).

${ }^{48}$ E.g. C. Harlow, Public and Private Law: Definition without Distinction, 43 MoD. L. R. 241, 265 (1980). M.J. Horwitz, The History of the Public/Private Distinction 130(6) U. PA. L. R. 1423, 1428 (1982). D. Oliver, Common VALUeS AND THE PUBLIC-PRIVATE DIVIDE ch. 11 (1999).
} 


\section{B. Otto von Gierke: The Social Role of Private Law ${ }^{49}$}

\section{Notes on the Text}

Otto von Gierke's The Social Role of Private Law is famous in German legal education for its critique of the momentous endeavor to draft a German Civil Code. It speaks directly to us today, in all countries, not just because much of what Gierke advocated became law, but also because we are witnessing so many European and global projects to codify principles of law. This is why it seemed useful to translate it into English. There are, of course, problems in translating, especially when a text contains poetic rhetoric or historical legal concepts. First of all, German places its verbs in the last place you would expect to find them. It holds the reader, with apparent delight, in suspense to the last moment to find out what was actually happening in the organized jumble of nouns and adjectives before the verb. Surprise may be a virtue, but the weary English translator must constantly rearrange the sentences, and sometimes add a full stop.

Second, the title I have used, The Social Role of Private Law, exemplifies a further problem with translating words (wherever they appear) in general. For "soziale Aufgabe," we could choose "social task." This fits the most obvious dictionary translation - but "task" suggests something too narrow. We could say "social function." This fits with much legal literature on functional analysis, but I am not sure Gierke would have agreed with all of that: He saw law as organic, not physical or mechanical. Law was an expression of social life, and life was less a means than an end. Another option was "social purpose," but then the word "role" seemed to be more natural, even if it does not appear under dictionary entries for "Aufgabe." Gierke favored metaphor, imagery, the idea of organic life, rather than objective action. So, this translation always favors a contextual rather than literal translation, or uncomfortable dictionary analogues. Any translator who makes this kind of choice assumes a certain license and risks that permission would not have been given. This is why different translators come up with different translations. Sometimes it improves the text, sometimes it is not as good. Sometimes meaning is authentically recreated, and sometimes the subtle shifts in meaning will generate a different image, compared to an original. But in fact, the same words can mean very different things to two English or two German readers, because those readers' experiences in life have attached different meaning to words. Some comfort to translators might come from Ludwig Wittgenstein's later philosophy of language, Philosophical Investigations (1953). It abandoned the idea that language entails a single "correct" image, whose underlying meaning could be atomically analyzed. In doing so, Wittgenstein came to favor the view that the meaning of words depends on their use. And necessarily, the use of words-over which no person, nor group, has a monopoly-will depend on the meaning with which the listener or reader receives them. It is plausible to think that everyone who has ever read Gierke in German, or in English, like any other text, will have understood

${ }^{49}$ Die soziale Aufgabe des Privatrechts (Berlin 1889); translated into English by Ewan McGaughey (2016). 
something distinct. Even more, a reader who reads something twice will usually see something new. We can appreciate something in a different way because over the passing time we may become a different person.

Third, parts of Gierke's lecture discuss legal concepts peculiar to German thinking, with Gierke inventing terms himself. The concept of a Herrschaftsverband, for example, later used by Max Weber has no easy conceptual analogue in English. It means "an association that is dominated by a leader for a particular purpose." A major example is an incorporated business, but it could include non-incorporated businesses, or charities, or maybe sport clubs. Here the translator must simply make a choice, none of which will be entirely satisfactory, and explain the context later. Last, for ease of reading, I have added topic headings, which are not in the original lecture, but help identify the structure of the script.

I can only hope I have done a good enough job, and I am grateful for the comments and encouragement from Kathrin Hamenstädt and Mathias Goldmann. Most of all, Liv Jores and Patrick Kessler gave indispensable, patient advice, and have my immense gratitude. Further comments and corrections from readers are more than welcomed. 


\section{Die soziale Aufgabe des Privatrechts}

Hochansehnliche Versammlung!

Reiner Wissenschaft ist nur die Frage zugänglich, was ist, nicht die Frage, was sein soll. So hat auch die Rechtswissenschaft als solche sich nur mit der großen geschichtlichen Wirklichkeit zu beschäftigen, die wir Recht nennen. Doch vermag sie schon in das Wesen und den Entwicklungsgang des Rechtes eine tiefere Einsicht nicht zu gewinnen, ohne daß sie den Zweck erforscht, der als unbewußter Gestaltgeber des Rechtes waltet. ${ }^{50}$ Wenn sie demgemäß fragt, welche Aufgaben im Leben der menschlichen Gesellschaft die Rechtsordnung in der Vergangenheit erfüllt hat oder in der Gegenwart erfüllt und welche Gedanken über diese Aufgaben auf die Rechtsbildung bestimmend eingewirkt haben oder einwirken, so verbleibt sie noch im Bereiche streng wissenschaftlicher Untersuchung. Sie kann indes nicht umhin, darüber hinauszuschreiten. Der Strom der Geschichte eilt vorwärts und bringt Wandlungen des Rechts, welche der Zukunft ihre Bahn weisen. Je weiter das Geistesleben vorgeschritten ist, desto entschiedener greift hierbei bewußte That ein. Ihr geht die Überlegung voran, was Recht sein soll. Und an dieser Überlegung muß sich die Rechtswissenschaft betheiligen.

${ }^{50}$ Der energische Hinweis hierauf bildet ein unvergängliches Verdienst von Jhering's großem Werke. 


\section{The Social Role of Private Law}

\section{Social Science and the Purpose of Law}

Most honorable gathering!

Pure science is only truly open to the question of "what is," not the question of "what ought to be." Legal science as such may be concerned with the great historical reality that we name "law." But it cannot win a deeper insight into the existence of law and the path of its development without exploring its purpose, which governs law as if it were an unconscious designer. ${ }^{1}$ If one asks which roles the legal order plays in the life of human society, historically or at present, and which ideas have decisively influenced or do influence these roles, we still seem safely within the field of scientific enquiry. Yet it cannot be helped that the boundary will be crossed. The currents of history hurry forwards and bring legal change, pointing to a future path. The more that intellectual life has progressed, the more conscious action becomes determinative. Behind it lies reflection upon what the law should be. And legal scholarship must take part in this reflection.

\footnotetext{
${ }^{1}$ This specific reference owes an immense debt to Rudolf von Jhering's great work.
} 
Zwar ist nicht sie allein hierzu berufen: das ganze Volk und jeder Bruchtheil des Volkes, den es angeht, soll erwägen, beschließen, handeln. Auch reicht sie hier mit den Mitteln, über die sie als Wissenschaft verfügt, nicht aus: nicht Wissen wird verlangt, sonder Weisheit, praktische Kunst, prophetischer Blick. Allein sie hat Gaben voraus, die für eine glückliche Lösung des Problems nicht ungenutzt bleiben dürfen. Aus dem Verständnis erwächst Liebe, aus der Einsicht in den Zusammenhang Gefühl für das Ganze, aus der Vertiefung in die Geschichte Sinn für das Künftige. Die Rechtswissenschaft würde sich selbst aufgeben, wenn sie in den großen Entscheidungsstunden des Rechtslebens schwiege. Sie kann und wird nicht darauf verzichten, Ziele zu setzen und den Gesetzgeber zu berathen.

Im deutschen Reiche stehen wir zur Zeit vor einer Entscheidung, die einen Markstein in der Geschichte des Privatrechts bilden wird. So wendet denn begreiflicher Weise die gesamte deutsche Jurisprudenz dem Plane, der mit der Veröffentlichung des Entwurfes eines bürgerlichen Gesetzbuches für das deutsche Reich feste Gestalt gewonnen hat, ihre ungetheilte Aufmerksamkeit zu. Erregte Erörterungen darüber, was Recht sein soll, drängen die historische und dogmatische Arbeit zeitweilig in den Hintergrund. Zahllose Einzelfragen tauchen auf. Aber auch die Grundfragen aller Rechtsbildung brechen hervor und werden zu brennenden Tagesfragen. In einem solchen Augenblick gilt es vor allem, sich zu besinnen, was denn eigentlich überhaupt die Aufgabe des Privatrechts ist. So erbitte ich mir die Erlaubnis, auch vor Ihnen, die Sie an der im deutschen Reiche fluthenden Bewegung den lebendigsten Antheil nehmen, von der Aufgabe des Privatrechts zu reden, - nicht zwar im ganzen Umfange der unermeßlichen Perspecktive, die mit diesem Worte sich aufthut, wohl aber in einer bestimmten Richtung, in der, wie ich meine, der deutsche Entwurf dessen nicht eingedenkt gewesen ist, was eine neue Privatrechtsordnung der heutigen Welt leisten soll. 
Of course, legal scholars should not be the only participants: The whole community and every group of the people which is concerned should consider, choose, act. Even here, the methods that legal science has at its disposal are not enough: It is not just knowledge that is required, but wisdom, practical skill, a predictive perspective. Yet legal scholarship does have qualities that cannot be overlooked for a satisfactory solution to problems. Out of understanding grows love, out of insight into context a feeling for the whole, out of immersion in history a sense of the future. Legal scholarship would have surrendered if it stayed silent during the great hours of decision in the life of the law. It cannot and will not abstain from setting goals and advising the legislator.

In the German Empire, we are standing in such a time of decision, which counts as a landmark in the history of private law. The whole of German jurisprudence has turned its undivided attention, and understandably since it took a firmer form, toward the publication of the draft for a Civil Code. Excited discussions about what is right have pushed historical and dogmatic work temporarily into the background. Countless detailed questions have emerged. But also basic questions of all legal education have burst forth and become the burning questions of today. In this moment, it matters above all else to understand what really is the role of private law. So, I ask permission before you, so that you may take the most active part in the swelling movement in the German Empire, to speak about the role of private law-certainly not in its entire breadth of inestimable perspectives, which these words might bring to mind, but in a particular direction in which, as I mean, and of which the German draft is not conscious: What a new private law order in today's world should achieve. 
Von der Aufgabe her haben schon die Römer in der durch den Mund Ulpians uns überlieferten Definition das Wesen des Privatrechts zu bezeichnen gesucht. Denn indem sie es als ein jus, quod ad singulorum utilitatem spectat, dem publicum jus, quod ad statum rei Romanae spectat, gegenüberstellen, führen sie den Unterschied der beiden großen Rechtszweige auf eine ungleichartige Zweckbestimmung zurück. Sicherlich haben sie hiermit den unverrückbaren Ausgangspunkt jeder Sonderung von Privatrecht und öffentlichem Recht festgestellt. Denn diese Sonderung ist ein Ausdruck der doppelten Bestimmung des Menschendaseins. Sie entspringt der Thatsache, daß jeder einzelne Mensch zugleich sich selbst und der Gattung lebt, daß der Einzelne eine Welt für sich, ein dem Universum gegenüber geschlossenes Ganze und doch auch Theil von höheren Ganzen, vorübergehende Erscheinung in dem Lebensprozeß von Gemeinwesen ist. Indem das Recht als äußere Lebensordnung diesen zwiefachen Gehalt des Menschenlebens vorfindet und demgemäß sich in zwei verschiedenartige Reiche gliedert, muß es sich auf der einen Seite die Begrenzung und den Schutz der äußeren Lebenssphären der Individuen, auf der anderen Seite den Aufbau und die Sicherung des Lebens der Allgemeinheit zum Ziel setzen. Allein es ist sofort klar, daß diese Trennung nicht das letzte Wort sein kann. Denn es bleibt derselbe Mensch, in dem sich ein individuelles Dasein und ein Stück des Gesamtlebens abspielt. Beides ist in Wirklichkeit zur unauflöslichen Einheit verflochten und wird nur in unserer Vorstellung gesondert. Was wir Individuum und was wir Allgemeinheit nennen, sind nur unentbehrliche begriffliche Abstraktionen, von der in ihrer Totalität für unser Denken unerfaßlichen Realität des geschichtlichen Menschen. ${ }^{51}$

${ }^{51} \mathrm{Vgl}$. Dilthen, Einleitung in die Geisteswissenschaften I S. $35 \mathrm{ff}$. 
In this task, and delivered to us through the voice of Ulpian, the Romans attempted to describe the essence of private law. It was a kind of law that came from a juxtaposition, the law, quod ad singulorum utilitatem spectat, dem publicum jus, quod ad statum rei Romanae spectat, ${ }^{*}$ which led them to ascribe dissimilar purposes to the two great branches of law. Without a doubt, they had determined an immovable starting point for every distinction between private and public law. Because this distinction expressed dual dimensions of human existence. It arises from the fact that every person lives simultaneously as oneself and as one of a kind, that every individual is a world unto himself, a universe against a unity and yet also a part of higher unities, transient phenomena in the life process of a common existence. Insofar as the law, as an external world order, encounters this two-dimensional content of human life, and accordingly constitutes itself in two distinct empires, on one side it must constrain and protect the external sphere of individuals' lives, and on the other side its goal must be to build and secure the life of the community as a whole. Yet it becomes immediately clear that this division cannot be the last word. It remains the same person who acts out both an individual existence and as a player in community life. Both are intertwined in reality as an indissoluble unity and are distinct only in our imaginations. What we call the individual and the whole are merely indispensable conceptual abstractions of, what is for us in its totality, the incomprehensible reality of historical humanity. ${ }^{2}$

\footnotetext{
" Private law is that "which concerns the individual's interests, while public law concerns the Roman state."

${ }^{2} C f$. Dilthen, Introduction to the Humanities vol I, $35 \mathrm{ff}$.
} 
So kann auch die Rechtsordnung, wenn sie sich in Privatrecht und öffentliches Recht spaltet, wohl eine Weile davon absehen, daß der Einzelne für das Ganze und das Ganze für die Einzelnen da ist. Allein zuletzt darf sie die Einheit des Zieles nicht vergessen und muß auch im Privatrecht, wo sie zuvörderst für die Einzelinteressen sorgt, das Gemeinwohl erstreben, und im öffentlichen Recht, wo sie zunächst auf das Ganze blickt, den Einzelnen gerecht werden. ${ }^{52}$

Daß die Römer bei der Ausgestaltung ihres welterobernden Rechtssystemes dies völlig versäumt hätten, wird niemand behaupten. Doch beruht die Eigenart des römischen Rechtes auf dem ursprünglich angelegten Übergewicht des Gegensatzes beider Rechtshälften über ihre Einheit. Die Römer hätten das Erbe der Menschheit niemals um den Gedanken eines selbständigen, dem Staate ebenbürtigen Rechtes gemehrt, wenn sie nicht den Gegensatz des jus singulorum und des jus populi mit kraftvoller Einseitigkeit verwirklicht hätten. Hier die Souveränität der Einen und untheilbaren Staatsgewalt, dort die Souveränität des Individuums, - das waren die gewaltigen Hebel der römischen Rechtsgeschichte. Großes, Unvergängliches ward so erreicht. Aber es kam der Tag, an dem diese Welt sich auslebte. Das öffentliche Recht erstarrte zur Verwaltungsordnung einer absolutistischen Staatsmaschine. Das römische Privatrecht entwickelte sich zu jenem kunstvollen System, das wir Alle bewundern. Allein in aller seiner klassischen Schönheit vermochte es den wirthschaftlichen Verfall, die sittliche Auflösung die soziale Zersetzung nicht aufzuhalten.

${ }^{52}$ Vgl. Jhering, Zweck im Recht, I S. 64, 82, 99: „Die Wahrheit des Satzes: Jeder ist für die Welt, und ist für Jeden da - das ist die Gesellschaft." 
The legal order, if it splinters into private and public law, can certainly ignore the importance of the individual for the whole and the whole for the individual," for a while. But in the end, the law cannot forget the unity of the goal. Private law, though it cares foremost for individual interests, must serve the common good. Public law, though it looks first to the whole, must be just toward individuals. ${ }^{3}$

\section{Law's Duality and Historical Development}

Nobody would maintain that the Romans, as they shaped their world-conquering legal system, had missed this goal completely. But the peculiarity of Roman law was its overemphasis of the opposition between both halves of the law over its unity. The Romans would have never been able to increase the inheritance of humanity around the idea of a law that was independent and equal to the state, if they had not created a strong and one sided opposition between the jus singulorum and the jus populi. ${ }^{\dagger}$ Here the sovereignty of the one and indivisible state power, there the sovereignty of the individual-those were the powerful levers of Roman legal history. Great, eternal things were accomplished. But the day came when the world lived past them. Public law ossified into the administrative apparatus of an absolutist state machine. Roman private law developed into the elegant system that we all admire. But in all its classical beauty it was incapable of preventing economic decline, moral dissolution, and social disintegration.

\footnotetext{
* Gierke's formulation is reminiscent of the phrase, Unus pro omnibus, omnes pro uno or "all for one and one for all."

${ }^{3} \mathrm{Cf}$. Jhering, The Purpose in the Law vol 1, 64, 82, 99 (1877), "The truth of the phrase: everyone exists for the world and the world exists for everyone - that is society."

† The "justice of the individual" and "popular justice."
} 
Mit seinem Nivellement der Personen wußte es der Sklaverei nicht beizukommen; es erhielt sich seine reinen Linien, indem es den Sklaven nach wie vor als Sache einreihte, aber das furchtbare Übel des sterbenden Alterthums wucherte fort. Gebaut auf diese ungeheure Lüge, ohne die er doch nicht denkbar war, stand der Individualismus des römischen Privatrechts allen das Leben des gesellschaftlichen Körpers unterhöhlenden Kräften rathlos und machtlos gegenüber. Wohl suchte die Kaisergesetzgebung durch mancherlei sinnreich erdachte Mittel die entfesselte Selbstsucht zu bändigen, den Schutz des Schwachen gegen den Starken nachzuholden, die gelockerten Bande der Familie neu zu festigen. Allein mit dem Grundgedanken des alten Privatrechts konnte und wollte sie nicht brechen. So vollzog sich das Verhängnis. Und erst auf den Trümmern der antiken Kultur nahmen neue jugendliche Geschlechter, die das, war unsterblich an ihr war, langsam der eignen Seele einpflanzten, mit ungeschulter Riesenkraft und dämmerndem Bewußtsein den Kampf um die Lösung des menschlichen Kulturproblems von Neuem auf.

Die Germanen traten mit unfertigem Staat und unfertigem Recht in die Geschichte ein. So blieb ihnen der Gegensatz von Privatrecht und öffentlichem Recht, der an der Eingangspforte der römischen Rechtsgeschichte steht, Jahrhunderte lang verhüllt. Dennoch war gerade in dieser Unvollkommenheit ihre Rechtsidee breiter und tiefer angelegt als die Rechtsidee der Römer. Indem sie nur ein einziges, überall sich selbst gleiches, allbeherrschendes Recht kannten, ergriffen sie mit der ganzen Kraft ihres Gemüthes den Gedanken der Einheit alles Rechtes. Nun war das öffentliche Recht der Gefahr ausgesetzt, in die Formen des Privatrechts einzugehen: aber es war durch und durch Recht! Das Privatrecht blieb unfrei, durch publizistische Beimischungen gebunden: aber es war durch und durch sozial! 
Because it levelled out persons it did not know how to get past slavery; it had simply drawn a line so that a slave still ranked as a thing, but that savage pestilence from antiquity's decay spread. Built on this tremendous lie, without which slavery was unthinkable, the individualism of Roman private law stood helpless and powerless in the face of society, and the power it incorporated. Of course, the imperial legislature constrained unbridled selfishness with many sensible and well thought out means, to ensure the weak were protected from the strong, to mend the broken bonds of family. Only, it could not and would not break with the basic idea of the old private law. So it laid the foundations of its own ruin. And then on the ruins of the antiquated culture, a new generation would take on what was undying and slowly implanted into their souls, with unschooled but gigantic force, and dawning consciousness, the fight to solve the problem of human culture afresh.

The Germans stepped into history with an unprepared state and unprepared law. So the antitheses of private and public law stayed, shrouding, as they did, the entrance to Roman legal history for hundreds of years. Nevertheless, in their very incompletion, their concepts were broader and more deeply anchored than the legal concepts of the Romans. They recognized a single, universally applicable and all-encompassing law. And they seized the concept of all law's unity with every fiber of their being. Now public law was exposed to the danger of adopting the models of private law: But through and through it was law! Private law stayed unfree, even if bound to an admixture of publicity: But through and through it was social! 
Es gab keinen sourveränen Staat und es gab kein souveränes Individuum. Der Staat blieb in den Einzelnen und in unzähligen gesellschaftlichen Gliederungen stecken; er überließ das geistig-sittliche Gebiet der Kirche und das wirthschaftliche Leben der Genossenschaft. Das Individuum blieb in der Gemeinschaft beschlossen; in Familie und Körperschaft ging es mit seinem Sinnen und Trachten auf.

Fremdartig blickt uns, die wir an geistige Freiheit gewöhnt sind, das Mittelalter an. Dennoch verdanken wir Alles, was wir vor dem Alterthum voraus haben, der langen und innigen Versenkung der europäischen Völker in diese das gesamte Dasein verstrickende Ordnung der sozialen Bindung und Unterscheidung. Reich und Kirche, das Ständewesen mit den bunten Abstufungen von Freiheit und Recht, von Beruf und Ehre, geistliches und weltliches Recht, Lehnrecht und Hofrecht, Land und Stadt, die Fülle der Genossenschaften, feudale und korporative Autonomie und Selbstverwaltung, Agrargemeinschaft und zünftige Organisation der geistigen und gewerblichen Arbeit, der feste Halt der Familie und das gebundene Erbrecht, die Verwebung des Grundbesitzes in das reiche Geflecht angeborner und gekorner Zusammenhänge, - das waren die Bildungen, in denen unsere Väter die Breite und Tiefe der modernen Kulture erarbeiteten.

Aber nicht ohne gewaltsamen Bruch rang sich aus dem Mittelalter die moderne Welt empor. Um die Schale zu sprengen, in welcher er gefangen lag, rief der christlich-germanische Geist den Geist des heidnischen Alterthums zu Hülfe. Auf allen Gebieten vollzog sich die Wiedergeburt der Antike. Und erst aus der Verschmelzung der Gedankenelemente des aufgelösten Mittelalters mit griechischen und römischen Gedankenelementen formte sich in schweren Kämpfen das Moderne. Nun entdeckte sich das Individuum und es entdeckte sich der Staat. Emanzipation das Individuum und Emanzipation des Staates wurden die Ziele, auf welche von unzähligen Punkten her eine anschwellende Bewegung hinarbeitete. 
There was no sovereign state, and there was no sovereign individual. The state was tied to the individual and to the countless community associations; it conceded the spiritual field to the church, and economic life to cooperatives. The individual remained dedicated to the community; in the family and community his thoughts and his aspirations flourished.

It appears unfamiliar to us - we who are accustomed to freedom of conscience-when we look at the Middle Ages. Nevertheless, we owe to that time everything that we have since the Ancients, the long and innermost immersion of the European peoples in this existentially embroiling order of social bonds and division. Empire and Church, those constants with their blotted shades of freedom and rights, of vocation and honor, spiritual and temporal law, feudal and manor law, country and city, the wealth of cooperatives, feudal and incorporated autonomy and self-government, agricultural communes and savory organizations of the intellectual and commercial work, the steady hold of the family and the binding law of inheritance, the interweaving of land ownership in the rich network of granulated connections - this formed the tuition from which our forefathers developed the breadth and depth of modern cultures.

But it was not without a violent break that the Middle Ages were wrestled into the modern world. To break free from the oppressive yolk, the Christian-Germanic spirit called upon the spirit of heathen antiquity for help. It brought the rebirth of antiquity in all areas. And through the fusion of elements of Middle Age thought with Greek and Roman wisdom, through bitter conflict, modernity was formed. Now individuality discovered itself, and the state discovered itself. Emancipation of the individual, and emancipation of the state became the goals to which, from innumerable points, a movement mounted. 
In dieser Umwälzung alles inneren und äußeren Seins spielte das wiedererweckte römische Recht eine führende Rolle. Mit dem römischen Recht ward die grundsätzliche Scheidung von Privatrecht und öffentlichem Recht, ward die Ausgestaltung des Privatrechts zur Machtsphäre der freien Einzelpersönlichkeit und die Ausgestaltung des öffentlichen Rechts zur Daseinsordnung eines abstrakten Staates errungen. Dies alles freilich zunächst in überaus gemäßigter Form, durchtränkt mit fortlebenden germanisch-mittelalterlichen Ideen, durchmischt mit Resten und Anfängen sozialrechtlicher Zwischengebilde. Allein mit stets wachsender Tendenz der Annäherung an ein Ideal, wie es das Naturrecht, der aufgeklärte Absolutismus, die französische Revolution stufenweise entschleierten. Bis es zuletzt schien, als sollten wirklich alle Schranken der neuen Centralmächte dem radikalen Ansturm erliegen und nur das freie und gleiche Individuum und der omnipotente mechanische Staat, der jeder Gemeinschaft entledigte Einzelne und die aus der Gemeinschaft der Menschen in den leeren Raum emporgehobene Allgemeinheit auf dem Kampfplatz bleiben.

Wäre es dahin gekommen oder käme es dahin, so ständen wir am Ende unserer Kulturentwicklung. Alle aufgespeicherten Schätze an geistigem und materiellem Besitzthum würden nicht hinreichen, einer atomisierten und mechanisierten Gesellschaft eine längere Lebensfrist zu erkaufen. Aber nicht entfernt ist irgendwo in Europa und am wenigsten auf deutschem Boden das antisoziale Programm der abstrakten Theorien verwirklicht worden! Und in unserem Jahrhundert hat eine von innen kommende Bewegung in Wissenschaft und Leben die verheerenden Fluthen zurückgestaut, verschüttete Quellen lebendiger Volkskraft wieder aufgegraben, neue Jungbrunnen voll sprudelnder Frische dem Gestein entlockt. 
In this revolution of everything internal and external Roman law, reawakened, played a leading role. The basic division of private and public law, private law's arrangement of power spheres by individual personalities, and public law's arrangement of an existential order underneath the abstract state, were taken from Roman law. This, however, was in an extremely moderated form, soaked with the living ideas of the German middle ages, mixed with relics and a genesis of an intermediate social law structure. With an ever-growing tendency an approaching ideal was gradually unveiled, as with natural law, enlightened absolutism, and the French Revolution. Until the end it seemed that the barricades of the new central powers would succumb to the onslaught of the radicals, and only free and equal individuals and the omnipotent mechanic state would remain in the field of conflict: Every individual unbound from community, and communities raised into an empty universe."

If it had come to that, or if it were to, we would have reached the end of our cultural development. All of the treasures accumulated, whether our intellectual or material possessions, would not be enough to buy more time for an atomized and mechanized society. But not far away, in Europe and certainly on German soil, the anti-social program of abstract theories has been realized! And in our century an indigenous movement of knowledge and life has held back devastating floods, sources of living power of people that were suppressed have been liberated, and the fountains of youth from a sparkling spring were brought forth.

* Gierke is referring here to the continuing struggles up to the Revolutions of 1848 . See generally, E. HOBSBAWM, THE AGE OF CAPITAL 1848-1875, ch 1, n.21 (1975). 
Die geschichtliche Schule, der Wiederaufgang des Volkstums, die Zurückverlegung des Staates in das Volk, das Wiedererwachen des Gemeinschaftsgeistes im Einzelnen, der ungeahnte Aufschwung des korporativen Gedankens in Kirche, Gemeine, Verein, und Genossenschaft, die Renaissance des deutschen Rechts, - dies Alles sind einzelne Seiten eines mächtigen Gesammtvorganges, der unserem Zeitalter die Züge neuer Jugend aufprägt. Inmitten solcher Wandlung stellt sich auch die Frage nach der Aufgabe der Rechtsordnung im Lichte eines neuen Morgens dar. Wir besinnen uns wiederum auf die Einheit alles Rechtes, wir nehmen in den Zweck des öfftentlichen Rechtes die Freiheit und in den Zweck des Privatrechts die Gemeinschaft auf.

Schauen wir wirklich die Morgenröthe eines jungen Tages? Oder leuchtet uns nur der Abendglanz einer versinkenden Welt? Streuen wir vielleicht nur Saatkörner aus, die nach dem Zusammenbruch unserer Kultur eine neue Gesellschaft in langsamer Überwindung ursprünglicher Barbarei zur Frucht entfalten wird? Etwa wie das Christenthum der untergehenden alten Welt nur noch den Trost ihres Lebensabends spendete und erst in der Seele der jugendlichen Barbarenwelt, der es als kostbares Erbe zufiel, sich zur Alles durchleuchtenden und durchglühenden Sonne entzündete? Es wäre vermessen zu antworten. Gewiß ist, daß unbeschwichtigte Gefahren furchtbarer Art im Schooße unserer Gesellschaft lauern. Gewiß aber ist auch, daß in dem Kampfe, den wir um den Fortbestand unserer Kultur kämpfen und kämpfen müssen, uns die Hoffnung auf den Sieg nur winkt, wenn wir uns mit dem aufstrebenden Gemeinschaftsgeiste erfüllen und aus ihm heraus Staat und Recht, Sitte und Wirthschaft sozial zu gestalten verstehen.

In diesem Zusammenhange erscheint die Frage nach dem Verhältnis zwischen öffentlichem Recht und Privatrecht als eine Lebensfrage der Gegenwart. 
The historic school, the re-emergence of collective identity, the retreat of the nation within the people, the re-awakening of the communal spirit in individuals, the unforeseen rise in communal thought in churches, congregations, clubs and co-operatives, the renaissance of German law-all of these are individual aspects of a powerful and general movement, which is imprinted in our times upon our youth. In the midst of such change, we face the question of the role of law in light of a new morning. We cast our minds back to the unity of all law. Our purpose in public law is freedom, and in private law it is community.

Are we really witnessing a new dawn? Or is it merely the twilight of a world in demise? Are we perhaps scattering seeds, which can only blossom slowly and overcome the barbarism that will follow the collapse of our culture? Are we something like the Christianity of the old world, whose only consolation was that as its life ended, it could ignite in the soul of a youthful barbarian world that chanced upon such a precious inheritance, like a radiant, glowing sun? To answer would be bold. What is certain, is that an unassuaged danger of a terrible kind is lurking in the core of society. But it is certain too that, in the battle for our culture that we are fighting, and fight we must, the hope of victory will only beckon if we come with an aspiring sense of community, and understand the social shape of our state and our rights, our traditions, and economy.

In this context, the relationship between public and private law becomes the critical question of today. 
Der scharfe, grundsätzliche Gegensatz ist für uns unantastbar. Wir können ihn nicht austilgen, ohne die Errungenschaften selbst, die wir schützen wollen, preiszugeben. Ist das öffentliche Recht nicht mehr die Daseinsordnung höherer Gesamteinheiten mit selbständigem Lebenszweck, sinkt es, statt der erhabenen Idee eines unsterblichen Gemeinwesens zu dienen, zum Mittel für die im Einzeldasein beschlossenen Zwecke aller oder der Mehrheit herab, so stürzt die mühsam erstrittene Hoheit des Staates! Erkennen wir im Privatrecht nicht mehr das Individuum als Selbstzweck an, verkümmern wir seine Ordnungen zu Mitteln des Gesellschaftszweckes, so hat das Christentum umsonst den unvergleichlichen und unvergänglichen Wert jedes Menschendaseins offenbart und die Weltgeschichte vergeblich die Ideen der Freiheit und der Gerechtigkeit entwickelt! Immer wieder regen sich mit elementarer Gewalt die Anschauungen und Bestrebungen, die einem verödeten Monismus der einen oder der anderen Art frönen. In gelehrten und ungelehrten Köpfen spuken auch heute die von der extremen Naturrechtslehre mit ihren Vertragstheorien systematisch ausgebildeten Vorstellungen, für welche, weil sie nur dem Individuum Realität zuerkennen, alles öffentliche Recht zuletzt von den einzelnen ausgeht und auf die einzelnen abzielt und darum nichts als ein verwickelteres Privatrecht ist. ${ }^{53}$ Von der anderen Seite her bedrohen die in den sozialistischen Lehren zum System erhobenen Gedanken, welche den Menschen ausschließlich als Glied der Gesellschaft begreifen und werten, alles Privatrecht mit der Umbildung in eine staatliche Verwaltungsordnung. ${ }^{54}$

\footnotetext{
${ }^{53}$ Wie tief auch in unsere Staatsrechtswissenschaft noch die atomistisch-mechanische Betrachtungsweisse, die im Grunde niemals über ein privatrechtliches Denken hinauskommen kann, eingesenkt ist, wollen wir hier nur andeuten.

${ }^{54}$ Es fehlt in der Privatrechtswissenschaft selbst nicht an Theorien, die solchen Auffassungen vorarbeiten. So die Angriffe auf das subjektive Recht. Lehrreich ist es, wie sich nach Vernichtung des subjektiven Rechts in dem Buche von Joseph Schein, Unsere Rechtsphilosophie und Jurisprudenz, Berlin 1889, das Privatrecht ausnimmt: alles Recht ist nichts als ein Inbegriff vom Staate kundgemachter Regeln, wie er selbst in vorkommenden Fällen sich zu verhalten gedenke, - vergleichbar dem Betriebsreglement der Eisenbahnen; das Privatrecht ist folgerichtig ein Anhang zur Zivilprozeßordnung.
} 
The sharp, basic opposition is inviolable for us. We cannot eliminate it entirely without sacrificing the very achievements we seek to protect. If public law ceases to be a unity of an existentially higher order, with an independent purpose, in place of the noble idea to serve an everlasting common existence, it is reduced to be the means of everybody to follow individual purposes, or simply the majority's purpose. With this, the hard-won sovereignty of the state would fall! In private law, if we cease to recognize the individual as an autonomous end in itself, if we paralyze its arrangements as a means for corporate purposes, the Christian revelation of each person's unique and immortal worth would be lost in vain. World history would have developed the ideas of freedom and justice for nothing! Again and again, ideals and aspirations stir with elementary force, that indulge a desolate monism in one way or another. Educated and uneducated minds are still haunted today by the extreme natural law position on contractual theories, which, because they acknowledge only an individual reality, always begin with the individual and get to public law last. Always directed toward the individual, it is therefore nothing more than a befuddled private law. ${ }^{4}$ On the other side, the socialist school of thought is threatening, as it sees and values people exclusively as members of society, and would translate all of private law into a branch of state administration. ${ }^{5}$

\footnotetext{
${ }^{4}$ We can only indicate briefly here how deeply the atomistic-mechanistic perspective is embedded in our constitutional law too, which at a fundamental level never can emerge from a private law paradigm.

${ }^{5}$ Private law science is not short on theories that offer such assessments. Hence the attacks on "subjective" law. Instructive on this point of the eradication of subjective law are the books of JOSEPH SCHEIN, OUR LEGAL PHILOSOPHY AND JURISPRUDENCE (Berlin 1889) which exempts private law: All law is nothing more than an exposition of rules made by the state, which behaves the way it pleases in cases that arise-comparable to standard business terms of the railways; it follows that private law is an appendage to civil procedure.
} 
Beiden Richtungen gilt der Kampf. Die Entstaatlichung des öffentlichen Rechtes im Sinne des naturrechtlichen Individualismus bedeutet die Auflösung und den Tod, die Verstaatlichung des Privatrechts im Sinne des Sozialismus bedeutet die Unfreiheit und die Barbarei.

Ist aber der Gegensatz unverlierbar, so müssen wir doch die Einheit über dem Gegensatz mit aller Kraft suchen und verwirklichen. Wir können mit dem großen germanischen Gedanken der Einheit alles Rechtes nicht brechen, ohne unsere Zukunft aufzugeben. Und mit diesem Gedanken ist ewig unvereinbar ein absolutistisches öffentliches Recht, ewig unvereinbar aber auch ein individualistisches Privatrecht. Wir brauchen ein öffentliches Recht, das durch und durch Recht ist; das ein Verhältnis der Gegenseitigkeit zwischen dem Ganzen selbst und seinem Gliede, zwischen der höchsten Allgemeinheit und allen engeren Verbänden, zwischen der Gemeinschaft und dem einzelnen setzt; das den Staat vom Scheitel bis zur Sohle durchdringt und bindet, auch da, wo der Zwang versagt, noch des Schutzes durch Richterspruch genießt; das zwar die Pflichten gegen das Ganze voranstellt, aber zugleich den Gliedern Rechte am Ganzen, dem geringsten Anteil am Staat gewährt und verbürgt; das von der Notwendigkeit und der Stetigkeit des Gemeinlebens ausgeht und doch die Freiheit in sich aufnimmt. ${ }^{55}$

\footnotetext{
${ }^{55}$ Dies Alles, was den Begriff des "Rechtsstaates" ausmacht und den Gedanken des "Kulturstaates" nicht in Frage stellt, haben wir hier nicht näher auszuführen. - Eine einzelne hierher gehörige Erscheinung hat Radnitzky, Die Parteiwillkür im öffentlichen Recht, Wien 1888, gut beleuchtet. Nur irrt er, wenn er in den von ihm zusammengestellten Fällen der freien Verfügung über öffentlichrechtliche Verhältnisse Anomalien erblickt und anscheinend deren künftige Beseitigung erwartet.
} 
There is a fight on both fronts. The de-nationalization of public law according to natural law individualism would mean dissolution and death, while the nationalization of private law according to socialism would mean tyranny and barbarism.

But if we are unable to abandon this antithesis entirely, we must still find and realize unity despite the opposition, and do so with all our power. We cannot abandon the great Germanic ideal of the unity of all law without giving up our future. This ideal will always be incompatible with an absolute public law, and it is equally incompatible with an individualistic private law. We need a public law, which through and through follows the rule of law; which recognizes reciprocity between the whole and its members, between the highest generality and the smallest associations, between the community and the individual; which binds and penetrates the state from peak to valley, even when coercion fails, and the protection of the courts is enjoyed; which certainly envisages duties toward the whole but at the same time gives members rights in the whole, guaranteed and secured in the smallest part of the state; which acknowledges the necessity and permanence of social life and yet embraces freedom. ${ }^{6}$

\footnotetext{
${ }^{6}$ This, which the concept of a "Rechtsstaat" amounts to and which the idea of a "culture state" does not question, needs no further detail. RADNITZKY, ARBITRARY POWER IN PUBLIC LAW (Wien 1888) highlights well a relevant phenomenon here. He is only mistaken insofar as he conceives cases of freedom of action over public law relationships as anomalies, and apparently expects their future disappearance.
} 
Wir brauchen aber auch ein Privatrecht, in welchem trotz aller Heilighaltung der unantastbaren Sphäre des Individuums der Gedanke der Gemeinschaft lebt und webt. Schroff ausgedrückt: in unserem öffentlichen Recht muß ein Hauch des naturrechtlichen Freiheitsraumes wehen und unser Privatrecht muß ein Tropfen sozialistischen Öles durchsickern!

Verlangen wir aber hiermit nicht einen Rückfall in verjährte Wirrnis, die sich mit den klaren logischen Grenzlinien moderner Systematik nicht verträgt? Gewiß ist es glatter und einfacher, das Prinzip des Gegensatzes folgerichtig auszubauen. Leider nur birgt dasselbe geradlinige Schema, das den mathematischen Sinn befriedigt, für das organische Leben, dessen Formen es setzen will, den Todeskeim. Ein großes geschichtliches Entwicklungsgesetz lehrt uns freilich, daß aller Kulturfortschritt der gesellschaftlichen Körper sich auf dem Wege der Differenzierung der geistigen Funktionen vollzieht: ursprünglich in demselben Keime ungesondert beschlossen, entfalten sie sich zu besonderen Lebensgebieten, spalten sich weiter und weiter, schaffen sich eigne Organe, treten einander in wachsender Selbständigkeit gegenüber, entwickeln sich eine jede ihrem inneren Wesen gemäß zu immer geschlossenerer Eigenart. Aber die Geschichte zeigt uns auch, daß in dem einseitigen Wirken dieser sondernden Kraft die gefährlichen Konflikte wurzeln, die das innere Leben des gesellschaftlichen Organismus erschüttern und ihn mit Zerreißung und Zersetzung bedrohen: der Widerstreit von Wissen und Glauben, von Macht und Recht, von Recht und Sittlichkeit, von Sittlichkeit und Sitte, von Bildung und Wirthschaft, von Kapital und Arbeit, der Zweispalt der Klassen und der Haß der Parteien. 
But also we need a private law, where despite the revered and inviolable sphere of the individual, the thought of community lives and weaves. Stated simply: Our public law should be blown a scent of natural law freedom and our private law must absorb a drop of socialist ointment.

But are we not demanding the reincarnation of old errors, such that are intolerable within the logical bounds of a modern system? Certainly it would be smoother and easier to extend the principle of antithesis. Unfortunately that same rigid linear scheme, which may well satisfy mathematical logic, ${ }^{*}$ spells doom for organic life, whose forms it would tame. A great rule of historical development teaches us that all cultural progress of the social body carries with it the distinction of spiritual functions: Originally unseparated and bound in the same seeds, they develop into special areas of life, diverge further and further, create their own organs, meet each other in growing independence, develop an inner existence always according to closed nature. But history also shows us that, within the uncompromising way of this special power lie the roots of dangerous conflict, which shake the inner life of the communal organ and threaten to rupture and corrode: The oppositions of knowledge and faith, of power and law, of law and morality, of morality and ethics, of education and economy, of capital and labor, the segregation of the classes, and the hate among political parties.

* This was probably a reference to Aristotle's arithmetic and geometric analogies to corrective and distributive justice. See ARISTOTLE, Nicomachean Ethics Book V, ch. 10. 
Alle Möglichkeit der Ueberwindung des lebenverzehrenden Trennungs-prozesses, alle Hoffnung auf Gesundheit und Leben beruht in dem Wirken einer anderen Kraft, welche nach dem immanenten Bildungsgesetz der organischen Lebenseinheiten zur Vereinigung treibt, die Gegensätze in einer höheren Einheit versöhnt und von der Einheit her die besonderen Funktionen mit Gemeinsamkeit durchdringt, das Auseinanderstrebende mit mächtigerem Streben bindet und das Getrennte ohne Aufhebung seiner Sonderart harmonisch zusammenfügt. Nur wo diese geheimnisvolle Kraft nicht erloschen ist, bedeutet der Fortschritt nicht den letzten Schritt jedes organischen Gebildes, - den Schritt zum Grabe.

So verläuft denn auch das Leben der Völker nicht in der schnurgeraden Linie einer logischen Evolution, sondern in dem Auf- und Abwogen lebendiger Kräfte. Ein System von Gedanken, Stimmungen und Zielen, das zeitweilig zur Vorherrschaft emporgestiegen war, tritt in das Dunkel zurück, und was unterlegen schien, erhebt sich in reiferer, freierer, vollerer Gestalt zu Macht und Sieg. Das sind die das Völkerleben verjüngenden Vorgänge der Erneuerung, der Wiedergeburt, der Erweckung von den Todten! Und ist dem so, dann wagen wir es auszusprechen, was den Ohren der meisten Juristen noch immer höchst befremdlich klingt: das Recht, welches uns heute formt, ist das erneuerte, das wiedergeborne, das aus todesähnlichem Schlummer erweckte deutsche Recht. Nicht das deutsche Recht in seiner mittelalterlichen Gewandung, aber das deutsche Recht in seinem unsterblichen Gedankengehalt. Jenes deutsche Recht, das vom fremden Recht zurückgedrängt, aber nicht erstickt werden konnte, das auch da, als es besiegt am Boden lag, den Eroberer umklammert hielt und immer wieder sich dienstbar machte, das nun schon seit langer Zeit unter wechselnden Schicksalen im Ganzen stetig die Führerschaft bei aller lebendigen Neugestaltung übernommen hat. 
Any possibility of overcoming the life-consuming process of separation, all hope of health and life is sustained by another power, which follows the immanent law of development for organic life and drives toward unification. It reconciles oppositions toward a higher unity and from unity impresses special functions with a common goal, which binds with a stronger force still than the force that pulls apart, and rejoins the divisions in harmony without neglecting their special forms. Only where this mysterious power survives is there progress, and not the last step of every organic form,-a step toward the grave.

Thus the life of people runs, not on an unswerving line of logical evolution, but with the ebb and flow of living forces. A system of thoughts, of tempers, and of goals, which temporarily rises toward dominance, may recede into darkness, and that which seemed subdued rises more maturely, more freely, and more fully formed for power and victory. They are the processes that rejuvenate the life of peoples, of renewal, of rebirth, awakening of spirits. And with this, we venture to say what still sounds strange to the ears of most lawyers, what forms today before us is a German law that is renewed, reborn, and with a spirit rekindled. Not German law in its medieval garb, but German law in its perpetual and conceptual essence. That German law, which was pushed away by foreign systems but could not be stifled, which just as it lay defeated was clasped by the conqueror, healed and made useful, which has now for some time, with changing fortunes, taken over the lead in living reorganization. 
Darum knüpfen wir, wenn wir ein wahrhaft zukunftsreiches Recht schaffen, so oft über die Episode der Fremdherrschaft hinweg an unsere große germanische Vergangenheit an. ${ }^{56}$ Und darum ist in der That der Kampf um das Recht der Zunkunft zugleich ein Kampf zwischen römischen und germanischem Rechtswesen. Was wir vom römischen Recht gelernt haben, wollen wir nicht verlernen, und dankbar wollen wir festhalten an der durch die wunderbare juristische Denkkunst der Römer gebildeten Form. Aber der Geist, der die Form beseelt, sei der Geist des Rechtes unserer Väter!

An den germanischen Rechtsgeist also wenden wir uns, wenn wir vor einer Neuordnung unseres Privatrechtes stehen, und von ihm empfangen wir die Mahnung, der sozialen Aufgabe eingedenk zu sein, die das Privatrecht in der heutigen Gesellschaft zu lösen hat.

Unverkennbar hat ja bereits ein durch unsere moderne Gesetzgebung hindurchgehender sozialer Zug auch dem Privatrecht an zahlreichen Stellen ein verändertes Gepräge verliehen.

\footnotetext{
${ }^{56}$ Treffende Bemerkungen über die Gründe der inneren Berührung zwischen modernem und älterem deutschen Recht macht V. Mataja, Das Recht des Schadenersatzes vom Standpunkte der Nationalökonmie, Leipzig 1888, - In den meisten Zweigen des öffentlichen Rechtes liegt eigentlich diese Erscheinung klar zu Tage. Dagegen pflegt auf dem Gebiete des Privatrechts von romanistischer Seite den germanistischen Bestrebungen immer noch vorgeworfen zu werden, daß sie zwischen reaktionären Versuchen der Wiederbelebung "abgestorbener" Gebilde des feudalen Mittelaters und schwärmerischen Träumereien über ein unreifes Zukunftsrecht schwanken. In welchem Umfange auch hier bereits die Gegenwart verjüngte Gedanken des alten deutschen Rechts verwirklicht hat, wird verschwiegen.
} 
This is why we return, when we seek to fashion a genuine law for the future, not to the episodes of foreign domination, but to the great Germanic heritage. ${ }^{7}$ And this is why in actuality the conflict over the future of the law is simultaneously a conflict between the essence of Roman and Germanic law. We must not forget what we have learned from Roman law, and we should hold gratefully and tightly to the wondrous art of juridical thought that the Romans pioneered. But the spirit which animates the form is the spirit of the laws of our forefathers.

\section{Legislative Change}

When we stand before a new order of our private law, we turn toward the German legal spirit, and hear its whisper to remember the social role which private law must play in today's society.

A train of social enactments have left the modern legislative scheme, including private law, unrecognizable, lending in numerous places a new character.

${ }^{7}$ V. MATAJA, The LAW of Compensation from a NATIONAL ECONOMic PeRSPECtiVe (Leipzig 1888) makes relevant remarks about the reasons for the inner shifts between modern and ancient German law. In most branches of public law this phenomenon is as clear as day. Against this, the Roman perspective on the field of private law still reproaches the Germanic efforts as drifting between reactionary attempts for resuscitation of "dead" models of the feudal middle ages and quixotic dreams about immature future laws. It fails to mention to what extent the ideas of old German law persist in the present. 
Gerade diejenigen neuesten Gesetze, die mit dem besonderen Namen "sozialpolitischer" Gesetze bezeichnet zu werden pflegen, greifen tief in privatrechtliche Gebiete ein. Doch ist es ein verhängnisvoller Irrtum, - ein Irrtum, den der Entwurf des deutschen Zivilgesetzbuches begangen hat, wenn man meint, man dürfe das soziale Werk den Spezialgesetzen überlassen, um unbelästigt durch die so abgewälzte Aufgabe das gemeine Privatrecht rein individualistisch auszugestalten. ${ }^{57}$ Man erhält nun zwei von ganz verschiedenem Geiste beherrschte Systeme: ein System des gemeinen Zivilrechts, in welchem das "reine" Privatrecht beschlossen liegt, und eine Fülle von Sonderrechten, in denen ein vom öffentlichen Recht her getrübtes und mit öffentlichem Recht vermischtes Privatrecht waltet. Hier lebendiges, volkstümliches, sozial gefärbtes Recht voll innerer Bewegung, - dort eine abstrakte Schablone, romanistisch, individualistisch, verknöchert in toter Dogmatik. Nun mag sich, unbekümmert um die ketzerischen Sonderrechte, das eigentliche und wahre Privatrecht in aller seiner logischen Pracht entfalten. Die Sonderrechte aber mögen zusehen, wie sie auf dem Boden eines solchen gemeinen Rechtes sich mit der privatrechtlichen Logik abfinden. Und das gemeine Recht ist doch der mütterliche Boden, aus dem auch die Sonderrechte hervorsprießen; an ihm lernt die Jugend das juristische Denken; aus ihm saugt der Richterstand seine Nahrung! Welche unheilvolle Kluft tut sich da auf! Welcher Zwiespalt zwischen dem Geiste der ordentlichen Rechtspflege und dem Geiste der Verwaltung und der notgedrungen stets weiter erstreckten Verwaltungsjuristdiktion! Welche doppelte Gefahr der Erstarrung und Verkümmerung der Jurisprudenz und der Überflutung des Rechtes durch den entfesselten Strom des öffentlichen Lebens!

${ }^{57}$ Gut hierüber Mataja a. a. D. S. 114 Note. 
The most recent Acts, which are often described with the special title of "socio-political" Acts, ${ }^{*}$ reach deep into private law territory. Yet it is a mistake of no minor consequence-a mistake which the German Civil Code draft has made - if one thinks it possible to relegate social enactments to special statutes, and with those tasks shuffled off the scene, leave the common private law to be purely individualistic. ${ }^{8}$ We are left with two systems, each dominated by wholly different ethics: one system of the common civil law, in which the "pure" private law is determined, and a mass of special rights, in which public law mars or mixes with private law administration. Here the living, popular and socially colored law, full of inner movement, - there like an abstract stencil, romantic, individualistic, ossified in obsolete dogmatism. The genuine and true private law now seeks, unperturbed by the heretical special rights, to flourish in all of its logical splendor. Yet the special rights attend to how they, from the foundations of such a common law, can face up to private law's logic. And the common law is the maternal foundation, from which special rights have sprung forth; from this the youth learn to think juridically; and from this the judicial establishment receives its sustenance. What a sinister chasm it opens! What a division between the ethics of civil and criminal courts and practitioners on the one hand, and the ethics of civil service, with the necessarily expanding jurisdiction of administration, on the other! How the danger is doubled, of jurisprudence becoming solidified, atrophied, and the overflowing of law through the unfettered energy of public life!

\footnotetext{
* Gierke is referring to reforms such as the Krankenversicherungsgesetz 1883 (Health Insurance Act 1883) Altersund Invaliditätsversicherunggesetz 1889 (Old Age and Invalidity Act 1889).

${ }^{8}$ Good on this point, ibid, Mataja (1888) 114, note.
} 
Nein! Ein gemeines Privatrecht, das seinen Beruf erfüllen will, muß tief genug gegründet und hoch genug gewölbt sein, um alle diese Sonderrechte in seinen Gedankenbau aufzunehmen. Dann aber muß der Gemeinschaftsgeist das Privatrecht von unten auf durchdringen.

Die soziale Aufgabe des Privatrechtes beginnt schon, wo es die einfachen Grundverhältnisse des Individualvermögens normiert. Sie steigert sich freilich in demselben Maaße, in welchem das Privatrecht zugleich dauernde Personen-verbindungen setzt und ordnet.

Zunächst hat ja das Privatrecht individuelle Vermögensmacht zu gewähren und zu begrenzen. Es erkennt Befugnissphären an, die dem Einzelnen eine frei für den individuellen Lebenszweck verwendbare Herrschaft über die äußere Güterwelt sichern. Allein gleich hier entsteht die Frage, ob es denn, wie dies unsere Pandektensysteme als selbsverständlich annehmen, den Begriff der reinen Befugniß zu Grunde legen kann und darf? In Wahrheit ist alles recht nicht einseitige, sondern gegenseitige Willsbeziehung. Auch das Sachenrecht ist zuletzt ein Verhältniß zwischen menschlichem Willem, nicht zwischen einem isolirten Einzelwillen und dem willenlosen Objekt. Wo aber Mensch und Mensch sich gegenüberstehen, da ist für unsere heutige Auffassung die pflichtenlose Herrschaft ausgeschlossen. So scheint doch auch das Privatrecht von dem Satz ausgehen zu müssen: kein Recht ohne Pflicht. In der That verknüpft schon unsere geltende Rechtsordnung auch mit dem stärksten und vollsten Recht, dem Eigenthum, eine Reihe von Pflichten. ${ }^{58}$ Dies sind aber keineswegs, wie es der romanistischen Denkweise vorkommt, einzelne Anomalien oder wohl gar Einstreuungen fremdartiger Bestandtheile "polizeilicher" Herkunft in das Privatrecht.

${ }^{58} \mathrm{Vgl}$. z.B. auch deut. Entw. $§ \S 734$ u. 735. 
No! A common private law that measures up to its task must have foundations deep enough, and its archways must reach high enough, to house all the special rights in its intellectual architecture. Yet then the community's spirit must come up to impress itself on private law.

\subsection{Property}

The social role of private law already begins when the basic relations of individual property are set. It is active to the very same extent, when private law sets and orders personal relationships over a period of time. ${ }^{*}$

First of all, private law both guarantees and delimits individual property rights. It acknowledges spheres of competence, where the individual is free to exercise appropriate sovereignty for his or her own purposes over the external world of goods. But here the question already arises, can the Pandectian system, which takes it for granted, leave the concept of unrestricted authority behind? In truth, it does not involve unilateral, but mutual relationships of wills. Even property law is, in the final analysis, a relationship between the wills of people, not between an isolated person's will and an inanimate object. But where one person confronts another, in today's world it is out of the question to have proprietary sovereignty without obligation. Private law should be seen to start with the same principle: No rights without duties. In fact, our contemporary legal order already ties property, with the strongest and fullest laws, to an array of duties. ${ }^{9}$ But these duties are in no way odd anomalies, as Roman thought would have it, or a scattering of foreign "police-like" elements in private law.

* BGB §314 acknowledges long term agreements, but they are terminable with good reason.

${ }^{9}$ Also compare, for example, the Draft German Civil Code §§734-735. 
Vielmehr handelt es sich um Folgesätze aus einem obersten Prinzip, das weiterer Enwicklung fähig und gar sehr bedürftig ist. Das pflichtenlose Eigenthum hat keine Zukunft! Wohl werden die höchsten sozialen Pflichten, die das Vermögen auferlegt, stets in das Gebiet der unerzwingbaren Gebote der Sittlichkeit fallen. Allein dasjenige, was der gesellschaftliche Zusammenhang unbedingt erheischt, muß zum Rechtsgebot erhoben werden. Der Ausbau der positiven Pflichten, welche den Befugnissen entsprechen, kann nur durch die ein jedes Rechtsinstitut im Einzelnen ausgestaltenden Bestimmungen erfolgen. In negativer Hinsicht aber bedarf es eines allgemeinen Satzes, welcher dem Mißbrauch des Eigenthums und der übrigen Vermögensrechte zum Schaden Anderer Schranken setzt. Kann die Rechtsordnung den richtigen Gebrauch der von ihr dem Individuum verliehenen Macht nicht erzwingen, so darf sie doch nicht mit verschränkten Armen zusehen, wenn diese Macht schnöde mißbraucht wird, um dem wahren Zweck des Rechtes Hohn zu sprechen. In diesem Sinne verbietet das preußische Landrecht die Ausübung des Rechtes zur Chikane. Der Entwurf des deutschen Gesetzbuches dagegen giebt die Chikane frei. Die Motive erblicken in der Freiheit des Mißbrauches gewissermaßen die Blüthe der privatrechtlichen Befugniß; ja bei der Rechtfertigung des Fehlens einer gegen sinnlose oder lediglich lästige Testamentsauflagen gerichteten Vorschrift erwärmen sie sich sogar für das durch die Testierfreiheit verbürgte Urrecht des mit Vermögen gesegneten Individuums, noch nach dem Tode andere Leute zu chikaniren. Seltsamer Weise denkt der Entwurf anders über den Mißbrauch der Freiheit. Während er die Schädigung Anderer durch chikanöse Ausübung eines besonderen Rechtes erlaubt, erklärt er eine "kraft der allgemeinen Freiheit an sich erlaubte Handlung" für "widerrechtlich", sobald sie "wider die guten Sitten verstößt und einem Anderen zum Schaden gereicht" (§705). 
Rather, they are the consequences of one of the highest principles, which enables further development, and which is entirely necessary. Property without obligation has no future! * The highest social duties, which property extols, fall continually into the field of unenforceable obligations. But precisely those things which the community demands unreservedly must be raised to be legal obligations. Building positive duties to match proprietary authority can only succeed through specific and individual provisions in each legal institution. In the negative sense, this requires a general proposition, which sanctions the misuse of property and the other property rights to the detriment of others. If the legal order cannot compel the proper use of the power that it lends to individuals, it may not cross its arms in abstention, as that power is misused in disdain, to hold the true purpose of the law in scorn. In this sense, Prussian law forbids exercising one's rights in a way that causes a nuisance to others. But the draft of the German Civil Code lets nuisance run free. The preparatory reports capture some of the extent of freedom for abuse of private law power; in the justifications for an absence of rules against senseless or merely vexatious testamentary wishes, they even warm to the idea of testamentary freedom being an extension of an original right for the blessed individual to make a nuisance to others after they are dead. Rarely does the draft consider the abuse of freedom differently. While it allows harm to others through victimizing use of a particular right, it states that the "power of general freedom in permitted actions" is "unlawful" so long as it "works contrary to good faith or is used to harm others" (§705).

\footnotetext{
* The Weimar Constitution Article 165 soon enshrined the principle, Eigentum verpflichtet (Property carries responsibility), which is now found in the Grundgesetz, Article 14(2).
} 
Warum in aller Welt darf ich denn nicht so gut meine Freiheit wie mein Eigenthum oder meine Forderung nach Herzenslust zur Schädigung meiner Mitmenschen benützen, so lange ich nur blos Anstand und Sittlichkeit mit Füßen trete und nicht gegen ein spezielles Gesetz verstoße ${ }^{59}$ In Wahrheit ist das Eigenthum nicht heiliger als die Freiheit. Auch die "besonderen Rechte" sind nicht dazu da, um mißbraucht zu werden. In den gegen die Chikane gerichteten Sätzen kommt das lange verdunkelte deutsche Rechtsgewissen zum Durchbruch. Wollen wir unser Privatrecht vor gefährlicher Entartung und unberechenbaren Erschüt-terungen bewahren, so werden wir den altnationalen Gedanken, der sich hier nur schüchtern äußert, in ungleich kräftigerer Weisen entfalten müssen. Im Nothfall darf sogar die Rechtsordnung nicht davor zurückscheuen, nicht blos den Mißbrauch des Eigenthums zu verbieten, sondern auch die Pflicht des rechten Gebrauches in dem sozial gebotenen Umfange zu Rechtspflicht zu stempeln. Ist doch schon heute das Bergwerkseigenthum, das Erfinderrecht, zum Theil auch das Jagdrecht mit einer derartigen Verbindlichkeit durchmischt. ${ }^{60}$ Zuletzt aber ist jede privatrechtliche Befugniß dem Einzelnen nicht blos um einer selber willen verliehen, sondern gleichzeitig als ein Kulturmittel anvertraut, dessen er sich zum Wohle der menschlichen Gesellschaft wirklich bedienen soll. ${ }^{61}$

\footnotetext{
${ }^{59}$ Ueber die Unhaltbarkeit dieser Unterscheidung und ihre sonderbaren Konsequenzen vgl. meinen Aufsatz in Schmoller's Jahrb. XIII S. $251 \mathrm{ff}$.

${ }^{60} \mathrm{Im}$ Forstrecht, Wasserrecht, Agrarrecht begegnen ähnliche Erscheinungen. Auch das Erlöschen von Rechten durch Nichtgebrauch in längerer Frist läßt sich vergleichen.

${ }^{61}$ Ließen Latifundienbesitzer nach schottischem Muster große Bodenflächen zu Sportzwecken wüßt liegen, würden Getreidevoräthe behufs Preissteigerung in Nothzeiten aufgespeichert oder gar vernichtet, - sicherlich würde es der Beruf des Rechtes sein, den rechten Gebrauch zu erzwingen.
} 
Why on Earth may I not use my freedom, as much as my property or my legal claims, according to whim to the detriment of fellow citizens, so long as I simply behave decently in good faith and do not contravene a special law ( $^{10}$ In truth, property is no more holy than freedom. Moreover, the "special rights" are not there to be abused. The long-obscured conscience of German law breaks through in the provisions directed against victimization. If we seek to protect our private law from dangerous evasion and unforeseeable agitation, we must develop the old national ideal, which at the moment has only been timidly expressed, in bold new ways. In emergencies the legal order must not shy away from, not simply prohibiting the abuse of property, but also to impress duties for its just use in a socially productive manner. In fact property over mines today is already, through the law on discovery, and in part also the law on hunting, mixed through with such obligations. ${ }^{11}$ In the end, every private law power of an individual is not conferred merely for the purpose of his own will. Simultaneously, it is entrusted to the individual as a means to cultivate and serve the good of human society. ${ }^{12}$

\footnotetext{
${ }^{10}$ On the unsustainability of this distinction and its particular consequences, compare my essay in Schmoller's Jahrbuch (1889) XIII, $251 \mathrm{ff}$.

${ }^{11}$ Similar phenomena are encountered in forestry law, water law, agricultural law. Compare the limitation of rights through non-utilization over a long time.

12 If owners of great estates (Latifundium) had knowingly left large areas of land to be used for sport purposes according to the Scottish example, or if grain-hoards during price rises and emergencies were stored or simply destroyed, - surely it would be the task of the law to compel its proper use.
} 
Mit dem Satze "kein Recht ohne Pflicht" hängt innig unsere germanische Anschauung zusammen, daß jedes Recht eine ihm immanente Schranke hat. Das romanistische System an sich schrankenloser Befugnisse, welche nur von außen her durch entgegenstehende Befugnisse eingeschränkt werden, widerspricht jedem sozialen Rechtsbegriff. Uns reicht schon an sich keine rechtliche Herrschaft weiter, als das in ihr geschützte vernünftige Interesse es fordert und die Lebensbedingungen der Gesellschaft es zulassen.

Damit entfällt der absolutistische Begriff des Eigenthums, wie er in unseren Pandektenlehrbüchern sich spreizt und vom deutschen Entwurf in die legale Form gebracht wird: "Der Eigenthümer einer Sache hat das Recht, mit Ausschließung Anderer nach Willkür mit der Sache zu verfahren und über diesselbe zu verfügen" (§848). Nun wird freilich alsbald hinzugefügt: "soweit nicht Beschränkungen dieses Rechtes durch Gesetz oder durch Rechte Dritter begründet sind". Und wenn wir Umschau halten, wie es im wirklich lebendigen Recht sich mit diesen Beschränkungen verhält, so entdecken wir, daß jene ausschließliche Willkürherrschaft eine bloße Fiktion ist. Aber diese Fiktion ist gemeingefährlich! Sie begründet eine Vermuthung für Schrankenlosigkeit und stempelt die Beschränkungen zu Singularitäten. Ihr liegt eine Überspannung des Eigenthumsbegriffes zu Grunde, über welche die Gegner alles Privategenthums fröhlocken mögen. Nein! Das Privateigenthum ist schon seinem Begriff nach kein absolutes Recht. Alle ihm im öffentlichen Interesse gesetzten Schranken mit Einschluß der Möglichkeit der Enteignung sind in seinem Begriff angelegt und entstammen seinem innersten Wesen. 
The principle of 'no rights without duties' is the internal bond of our Germanic view, that every right has implicit limits. The romantic system of unrestricted authority, which could only be limited by an external exercise of power, contradicts every social concept of law. We have had enough, and have no further use for legal domination other than that which is needed to protect reasonable interests and the conditions of life of the community.

With this passes away the absolutist concept of property, as the Pandectian textbooks elaborate it, and as the German draft has put it into a legal form: "The owner of property in a thing has the right, to the exclusion of others, to use it at his discretion, including its disposal" (§848). Only now, the following has been attached: "As long as the limits of this right are founded on law or the rights of third parties." ${ }^{*}$ And when we look around how these limits hold in real life, we discover that any exclusive and free-willed sovereignty is a pure fiction. But this fiction is a public danger! It invents a presumption that there are no limits and it conceptualizes the limits as singularities. Underlying this is an overreaching of the concept of property, about which the very opponents of all private property become jubilant. No! The concept of private property itself is not an absolute right. All the limits set according to the public interest, including the possibility of compulsory purchase, compose the concept, and derive from its innermost essence.

* Cf. BGB §903 today. "The owner of a thing may, to the extent that a statute or third-party rights do not conflict with this, deal with the thing at his discretion and exclude others from every influence." 
Darum ist es auch ein schädlicher Irrthum, daß das Eigenthum überall sich selbst gleich und von der Natur seines Gegenstandes vollkommen unabhängig sei. Vor Allem ist das Grundeigenthum seinem Inhalt nach von vornherein beschränkter als das Eigenthum an Fahrniß. Daß ein Stück unseres Planeten einem einzelnen Menschen in derselben Weise eigen sein soll, wie ein Regenschirm oder ein Guldenzettel, ist ein kulturfeindlicher Widersinn. In unserem Volksbewußtsein lebt unaustilgbar die von dunkler Erinnerung an den Ursprung des Grundeigenthums getragene und alle künstlichen Dämme immer wieder durchbrechende Anschauung, daß die Erde trotz aller Bodenauftheilung bis zu einem gewissen Grade stets Gemeingut geblieben ist, daß alles Sonderrecht am Boden nur mit einem starken Vorbehalt zu Gunsten der Allgemeinheit besteht. Und je nach der Beschaffenheit des Grundstückes scheint uns das Grundeigenthum selbst wieder von ungleichartigem Inhalte zu sein, so daß es an Landgütern und städtischen Bauplätzen und gewerblichen Anlagen besondere Herrschaftsbefugnisse gewährt, an Wald und Wasser in sehr gesteigertem Maße durch Gemeinschaftsrecht gebunden wird, an den dem Gemeingebrauch gewidmeten öffentlichen Stätten sich nahezu verflüchtigt. Unsere moderne Gesetzgebung hat trotz mancher Rückschläge - ich errinere an den preußischen Paragraphen betreffs den Beeren und Pilze - im Ganzen mehr und mehr sich von der lange Zeit vorwaltenden Sucht nach möglichster Verwirklichung der Souveränität des Individualeigenthums wieder losgesagt, das Recht der Gesammtheit am vaterländischen Boden kräftig gewahrt und die Unterschiede der natürlichen oder verkehrsmäßigen Zweckbestimmung zur Geltung gebracht. Wie aber stellt sich hierzu der deutsche Entwurf? 
For this reason it is a destructive misunderstanding to say that property is everywhere equal and completely independent from the nature of its object. Above all, the content of property in land is inherently more restricted than for moveable property. The idea that a part of our planet could ever belong to a single human being, in a manner identical to an umbrella or a purse, is a culturally endangering absurdity. In our people's conscience lives an indelible view about the source of property in land, from distant memories that break all artificial dams, that despite all the divisions on the ground up to a certain pitch, the earth has always remained common property, and that all rights in land exist only with the strongest reservation that they be used for the benefit of the community. And according to the type of the land, it seems that property in land must itself have different contents, so that special powers attach to agricultural land and building sites in towns and business premises, so that amplified rights of the community attach to forests and water reserves, which closely follow the common use of public places. On the whole our modern legislative system has, despite many setbacks-I am reminded of the Prussian sections concerning berries and mushrooms-but more and more, for a long time, and once again, contradicted the desire for the greatest possible realization of sovereignty over individual property. It has strongly protected the right of the community to the earth of the fatherland, and has drawn the distinction between use for regular or for business purposes. But what does the German draft do here? 
Alle im öffentlichen Interesse bestehenden Beschränkungen des Grundeigenthums aus dem reinen Privatrecht und somit aus seinem Gesichtskreis verbannend, nur die aus dem Nachbarrecht fließenden gegenseitigen Belastungen als Ausnahmen anfügend, erklärt er grundsätzlich das dem Eigenthümer eines Grundstückes zustehende Recht für eine ausschließliche und willkürliche Herrschaft, welche den ganzen Raum über der Oberfläche und den Erdkörper unter derselben ergreift (§849). Welche vermessene, allen Bedürfnissen und Anschauungen des Lebens widersprechende Vorstellung! Bis zum Mittelpunkt seines feurigflüssigen Innern ist unser Planet sammt dem ihm umschließenden Weltenraum zu Sonderrecht aufgetheilt! Der Alpenbesitzer, welcher entdeckt, daß der Bergtunnel gerade unter seinen Matten liegt, mag eine Strecke desselben sperren. Läuft ein Telephondraht über einen Winkel meines Grundstückes, so mag ich ihn durchschneiden. Der Luftschiffer muß erst die Erlaubniß aller Grundbesitzer einholen, deren Luftraum er durchfahren will. Wer nicht Grundbesitzer ist, thut eigentlich keinen legitimen Athemzug ohne fremde Gestattung. Das ist nicht blos unsoziales, das ist antisoziales Recht! Gerade wer dem Grundeigenthum wohl will, kann nicht scharf genug betonen, daß dasselbe keine den Sachkörper absorbirende Alleinherrschaft, sondern in letzter Instanz nichts als ein begrenztes Nutzungsrecht an einem Theile des nationalen Gebietes ist.

Hier wurzelt zugleich das Bedürfnis eines besonderen Immobiliar-sachenrechts, das den Erwerb und Verlust, die Veräußerung, Belastung und Verschuldung des Grundeigenthums im Einklang mit der Eigenart desselben abweichend von den für bewegliche Sachen geltenden Sätzen regelt. Bekanntlich hat in diesem Punkte das deutsche Recht auf der ganzen Linie gesiegt. Keine Neuordnung des Privatrechts kann eine andere Basis als das Grundbuchsystem wählen. Allein wir sind in Gefahr, durch formalistische Überspannung des Auflassungs- und Eintragungswesens das germanische Rechtsinstitut in sein Gegentheil zu verkehren und zuletzt die nationale Form mit dem Geist des fremden Rechts zu erfüllen. 
It has banished all limits on property in land in the public interest from its purist private law. It has only appended the opposing burdens as exceptions in neighboring laws. It explains the principle that the owner of property in land has a vested right to exclusive and arbitrary dominium, which encompasses everything from the heavens above the surface to the core of the earth (§849). What a blessed idea, contradicting all needs and perceptions of life! To the core of molten fire of our planet, and to outer space, divided into property rights! The owners of land in the Alps who discover that a tunnel lying beneath the mountain may block up the path. If telephone-cables run over a single corner of my land, I may cut them. An air pilot must first seek the permission of the landowner, whose airspace he wishes to cross. Whoever has no property actually draws no legitimate breath of air without another's license. That is not simply unsocial, but an anti-social law! Whoever wants to be sure of property in land cannot emphasize enough that he has, not an all absorbing individual dominance, but in the last instance nothing but a limited right to use a part of the national territory.

Here lie the roots of the need for a specific land law, where acquisition and forfeiture, alienation, encumbrance and indebtedness of ownership in land is regulated by provisions in harmony with its unique nature, and distinct from movable things. German law has a successful record in these points. No reform of private law could choose a basis other than the land registration system. ${ }^{*}$ Yet we face the danger, with formalism overshadowing the conveyancing and registration system, of placing this German legal institution into opposition, and eventually to instill the spirit of a foreign law into a national form.

\footnotetext{
* The Prussian Grundbuchordnung 1872 (Land Registration Order 1872)-which would have applied at the time of writing-went back much earlier.
} 
Nur allzu deutlich offenbart dies der deutsche Entwurf. Wenn wir jedoch mit der öffentlichen Kontrolle und Bekundung der Rechtsverhältnisse an Grundstücken nichts als eine staatlich gewährleistete Mobilisirung des Grundbesitzes erreichen, so werden wir zwar einen sehr freien, sehr prompten und sehr sicheren Verkehr mit Bodenwerthen erzielen, aber die große soziale Funktion des Grundeigenthums, die innige Verknüpfung von Einzelnen und Familien mit der Scholle, die Wahrung des Ständigen, Traditionellen, Heimathlichen in Gesinnung und Sitte, die feste Einwurzelung und kräftige Gliederung des gesellschaftlichen Körpers werden wir untergraben. Ein Privatrecht, das seinen sozialen Beruf begreift, muß auf die Stetigkeit des Grundbesitzes hinarbeiten. Es darf sich weder durch doktrinäre Gesichtspunkte noch durch herrschende kapitalistische Anschauungen zum Nivellement der Sachen verlocken lassen. Bei aller Anerkennung der Verfügungsfreiheit muß es Schutzwehren gegen Selbstzerstörung des Grundeigenthums durch Verschuldung und Zersplitterung errichten. Es muß den Versuch unternehmen, zunächst wenigstens neben den kapitalistischen Verschuldungsformen die dem Wesen des Grundbesitzes allein angemessene Verschuldungsform der dinglichen Rente dergestalt auszubilden und zu fördern, daß sie in einen ernsthaften Wettstreit mit Hypothek und Grundschuld treten kann. Wie die Zwangsvollstreckung in die gewerblichen Produktionsmittel und in den Arbeitslohn, so muß die Zwangsvollstreckung in die Existenzgrundlage eines landwirthschaftlichen Betriebes, in den Boden und das Gutsinventar beschränkt, dem Schuldner eine Heimstätte gesichert werden. Die hier und da begonnene Reform des Erbrechts in ländliche Güter darf nicht stillstehen, bis durch den Ausbau eines kräftigen Anerbenrechts die dauernde Erhaltung des deutschen Bauernstandes, des stärksten Bollwerks gegen äußeren Ansturm und inneren Umsturz, gewährleistet ist. ${ }^{62}$

62 Inzwischen ist in Österreich durch das Zustandekommen eines Höfegesetzes ein wichtiger Schritt in dieser Richtung getan. 
The German draft makes this all too clear. But if we do not achieve a state guarantee of marketability of land through the public control and evidence of legal relationships, we will still have a very free, very prompt and very safe transfer of land's worth. But the great social function of property in land, the inner connection between individuals and families with their homes, the guarantee of continuity, tradition, a sense of home in disposition and spirit, the secure bonds of membership in the communal body, would be buried. A private law, which understands its social vocation, must understand the continuity of land. It must not let itself be distracted either by doctrinaire points of view, nor by the dominant capitalist view in the levelling of property rights. All recognition of free disposition must be founded on protection against self-destruction of land ownership through over-indebtedness and fragmentation. An attempt must be undertaken to develop and require a proprietary annuity, at least alongside capitalist forms of debt, which can be a serious competitor to mortgages and land charges. As it does when business production and employment is affected, civil enforcement must guarantee the debtor a homestead when it affects the basis of livelihood in an agricultural business, in the land and inventory. Reform of the law for inheriting land, which has begun from time to time, cannot stand still until German farmers are guaranteed the strongest bulwark against external attack and internal subversion, through the creation of a strong agricultural inheritance law. ${ }^{13}$

${ }^{13}$ Recently in Austria, an important step forward has been made with the coming into force of a new Land Inheritance Act. 
Ueberall aber gilt es auch hier, die Nivellirungssucht, an der unsere Zeit krankt, zu bändigen, örtlichen und sachlichen Unterschieden gerecht zu werden. Kein abstraktes Dogma darf uns verleiten, die Geschlossenheit von Höfen, wo sie eingelebt ist, und wohlthätig wirkt, zu beseitigen; und geht es nicht anders, so müssen wir neue Theilungsbeschränkungen einführen. Die Erfahrungen, die wir mit dem freien Eigenthum gemacht haben, geben uns kein Recht, das gebundene Eigenthum, soweit es sich als lebensfähig bewährt, gewaltsam zu zertrümmern. Auch der in geschichtlichen Familien befestigte Großgrundbesitz erfüllt eine wichtige nationale und soziale Funktion, die jedoch zum Unsegen ausschlägt, wo sie über das gesunde Maß hinausgreift. Darum ist es eine der dringendsten Aufgaben des modernen Privatrechts, die Familienfideikommisse in die erforderlichen Schranken zu weisen, in diesen Schranken aber, ihrer eigentlichen Idee gemäß, zu wahrem Familieneigenthum auszugestalten. ${ }^{63}$ Ein einheitliches deutsches Gesetzbuch, das gleich dem Entwurf an allen diesen Fragen achselzuckend vorübergeht und ihre Lösung den Partikularrechten aufbürdet, verfehlt seinen Beruf.

Der sonderbarste Aberglaube, der sich mit dem romanistischen Eigenthumsbegriff verknüpft, und den ganzen deutschen Entwurf durchzieht, besteht in dem Dogma, daß das Eigenthum ein von allen übrigen Rechten spezifisch verschiedenes Recht ist, ein Recht, das gewissermaßen die Sache selbst aufzehrt, sich mit einem Stück der Körperwelt deckt und nur noch für Rechte von völlig anderer Struktur Raum läßt. Daraus ergiebt sich insbesondere ein niedrigerer Rang der begrenzten dinglichen Rechte.

${ }^{63}$ Näheres hierüber und über das Anerbenrecht in meinem Aufsatz über die Stellung des bürgerlichen Gesetzbuches zu der Erbfolge in ländlichen Grundbesitz in Schmoller's Jahrb. Bd. XII S 401-436. 
Above all it is necessary to control the desire for complete equalization which infects our times, and to re-orient it towards material differences. We should not be led by abstract dogma to abandon the cohesion of farming communities, their settledness and their altruism; and if it cannot be different, we must introduce new restrictions on division. The experience that we have had of free property rights gives us no right to violently shatter encumbered property so long as it proves to fulfil the purpose of enabling a livelihood. Even the massive estates owned by historical families fulfilled an important national and social function, though it is now condemned for its unhealthy excesses. There is one of the most urgent roles for modern private law, to create the necessary boundaries for a family trust, ${ }^{*}$ but in those boundaries to protect the family form of property. ${ }^{14} \mathrm{~A}$ unified German code that would do the job, because the draft shrugs all these questions off and thrusts them into particular laws, is missing.

The most peculiar superstition of the Roman concept of property, which is seen throughout the whole German draft, is the dogma that property-out of all other rights-is specific and different, a right which devours the thing it attaches to, covering a piece of the tangible world, and leaving room only for rights of a completely different structure. From this follows the lower priority for restricted proprietary rights.

\footnotetext{
* The word Fideikommissee entailed the family as a unit owning property, and a head-historically this was the man-managing it for the benefit of family members.

${ }^{14}$ Further details on this and on inheritance law in my essay on the position of the German Civil Code towards succession in agricultural possession of land in Schmoller's Jahrbuch (1888) vol XII, 401-436.
} 
Zugleich aber erscheinen alle diese Rechte an fremder Sache als mehr oder minder anomale Gebilde, die es nach Zahl, Umfang und Wirkung möglichst einzuschränken gilt. Das erstrebenswerthe Ideal ist die Konzentration aller unmittelbaren Sacherrschaft in der Einen und untheilbaren Gewalt des souveränen Individualeigenthums. Diese Auffassung hat der befreienden Gesetzgebung, welche die zu drückenden Fesseln gewordenen Grundlasten beseitigt und einen vollfreien bäuerlichen Besitz wiederhergesetellt oder geschaffen hat, wesentliche Dienste geleistet. Nachdem indeß diese Aufgabe in der Hauptsache gelöst ist, müssen wir mit dem theoretischen Irrthum auch die praktischen Einseitigkeiten der herrschenden Richtung abstreifen. Die begrenzten dinglichen Rechte sind ebenso gute und schutzwürdige Rechte wie das Eigenthum selbst. Manche ältere Formen derselben sind mit unseren heutigen Kulture- und Wirthschaftsverhältnissen unvereinbar, andere stehen in voller Blüthe oder tragen den Keim einer reichen Zukunft in sich. Denn man darf niemals vergessen, daß jede Absplitterung dinglicher Rechte vom Eigenthum zugleich eine Gemeinschaft gründet, die Gemeinschaft aber hier wie überall die Fähigkeit besitzt, durch Verbindung und Ausgleichung verschiedenartiger Kräfte die Gesammtkraft über die Summe der Einzelkräfte zu erhöhen. Eine Servitut, die das belastete Grundstück wenig beschwert, dem herrschenden Grundstück dagegen einen unverhältniß-mäßigen Vortheil verschafft, steigert den Volksreichthum. Ähnlich kann es sich mit den Reallasten verhalten. In anderer Richtung dienen dingliche Gebrauchs- und Nutzungsrechte umfassenderer Art, dingliche Anwartschaftsrechte oder Vorkaufsrechte, dingliche Anrechte am Werth unter bestimmten Voraussetzungen als Kulturhebel. Darum darf in unserer von Individualismus bedrohten Zeit eine Privatrechtsordnung, welche soziale Ziele verfolgt, keineswegs die Rechte an fremder Sache zurücksetzen und ohne Noth einengen oder abschwächen. ${ }^{64}$

${ }^{64}$ Dies thut der deutsche Entwurf durch Beschränkung der Zahl der dinglichen Rechte, durch Verdrängung des Gestaltungsrechtes der Betheiligten aus dem ganzen Sachenrecht, durch Ausdehnung des Eintragungszwanges auf alle Grunddienstbarkeiten und durch vieles Andere. 
At the same time all these rights in things of third parties appear as anomalous constructs, that are to be limited as much as possible in their number, scope and effect. The ideal that is striven for is the concentration of all unintermediated dominium over things in one undivided power of sovereign individual ownership. The enfranchised legislature has performed an essential service for this perspective, by eliminating encumbrances on property that had become burdensome shackles and again creating a completely free form of agricultural possession. Insofar as the main issue has been resolved, we must shed the theoretical errors as much as the practical one-sidedness of the dominant direction. Restricted property rights are equally good and worthy of protection as rights of property themselves. Many older forms of the same are incompatible with our contemporary culture and economic relations, while others stand in full bloom or carry the seeds of a rich future. One must never forget that the fragmentation of property rights simultaneously founds a community, but the community which everywhere possesses the ability, through obligation and distribution of different types of powers, to raise the power of the whole above the sum of its parts. A servitude, which places a small burden on the encumbered land, and creates a disproportionate advantage for the dominant tenement, increases social wealth. This can happen in a similar manner with real security. In another direction, proprietary usage rights of all kinds, proprietary anticipation rights or pre-emption rights, proprietary claims of value serve under certain circumstances as levers of culture. This is why in our time, as we are threatened by individualism, a private law order that pursues social objectives should never erase rights in things of third parties and without necessity constrain or weaken them. ${ }^{15}$

\footnotetext{
${ }^{15}$ This is what the German draft does through limitations on a number of proprietary rights, through suppression of formation of rights by participants in the whole of property law, through the extension of the duty to register all land servitudes, and through much more.
} 
Sie muss sich vielmehr deren sorgfältigem Ausbau widmen. Und nach zwei entgegengesetzten Seiten hin wird sie von hier aus das romanistische Schema durchbrechen müssen. Auf der einen Seite wird sie die Brücken, welche das germanische Recht zwischen Obligationsrecht und Sachenrecht schlägt, nicht einem doktrinären Trennungsschnitt zu Liebe abzubrechen, sondern zu befestigen und auszubauen haben. ${ }^{65}$ Der dingliche Zug der auf Sachbesitz abzielenden oder mit Sachbesitz verbundenen Obligationen, die Möglichkeit voller Verdinglichung eines obligationsrechtlichen Inhalts, - in diesen germanischen Rechtsgedanken lag und liegt eine Welt sozialer Ausgleichung beschlossen. So gäbe es keinen größeren Verstoß wider die soziale Aufgabe des heutigen Privatrechts, als wenn das deutsche Gesetzbuch nach dem freilich ja schon so gut wie gerichteten Vorschlage des Entwurfes Pacht und Miethe romanisieren, den Satz "Kauf bricht Miethe" durchführen, dem Pächter ein dingliches Recht an den mit seinem Schweiß und seinen Kosten dem Boden entlockten Früchten absprechen, ${ }^{66}$ durchweg jede unmittelbare Beziehung des Pächters und Miethers zur Sache verneinen und nur eine in jedem Augenblicke sich erneuernde persönliche Forderung auf Gewährung der Sache anerkennen wollte!

\footnotetext{
65 Das Aeußerste in der entgegengesetzten Richtung der Auseinanderreißung beider Rechtstheile leistet der deutsche Entwurf: Sachenrecht und Obligationenrecht sind ihm zwei Welten für sich.

${ }^{66}$ Hier greift zugleich ein anderer sozialer Verstoß des Entwurfes ein: die Regelung des Fruchterwerbes nach dem römischen Substanzialprinzip, die Verwerfung des deutschen Produktionsprinzips, des Satzes vom verdienten Gut ("Wer säet, der mähet"), welcher der Arbeit giebt, was ihr gebührt; vgl. meinen Aufsatz in Schmoller's Jahrb. Bd. XIII S. $216 \mathrm{ff}$.
} 
Rather, it must pursue their careful extension. And from here, it must break through the romantic scheme on two opposing fronts. On one front, it will not break down the bridges, as German law is currently attempting, between the law of obligations and property for the love of doctrinal distinctions, but will secure and improve them. ${ }^{16}$ The proprietary pull of obligations that are directed or connected to possession of things, the possibility of complete proprietization of the content of obligations, - in these German legal ideals a world of social equality did and does reside. There would be no greater violation of the social role of contemporary private law than if the German code, following the practically compulsory suggestion of the draft to Romanize leases and rent, introduced the sentence "sales break leases," "* deny a tenant real property rights in the fruits of the effort and expense he had put into the ground, ${ }^{17}$ so that any direct relationship of the tenant and renters to a thing could be denied, and at any moment a new personal demand would be recognized and guaranteed in the property!

${ }^{16}$ The German draft achieves the opposite choice in the most extreme direction: For it, the law of property and obligations are two worlds apart.

* Now, BGB $§ 566$ was reformed to do the exact opposite, so that "Kauf bricht nicht Miete" (sales do not break leases). The English equivalent is the Land Registration Act 2002, Sch. 3, para. 2.

${ }^{17}$ At the same time, the draft engages in another social violation here: The regulation for acquiring the fruits according to the Roman "subtantial principle," the rejection of the German "production principle," the principle of earned goods ("he who sows shall reap") according to who contributed the work; $c f$. my essay in Schmoller's Jahrbuch (1889) vol XIII, 216 ff. 
Auf der anderen Seite wird unser Privatrecht die vom germanischen Recht vollzogene Überbrückung der Kluft zwischen den Rechten an fremder Sache und dem Eigenthum nicht einfach verwerfen dürfen. Wohl hat das getheilte Eigenthum, das seine welthistorische Mission darum nicht schlechter erfüllt hat, weil man es nachträglich für "logische unmöglich" erklärt, in seinen alten Formen sich ausgelebt. Allein verwandte Gebilde können wir auch fernerhin nicht entbehren, so oft wir neue Schichten des Volkes zu eignem Besitz an Grund und Boden emporheben und zur Seßhaftigkeit erziehen, innere Kolonisation mit dauerndem Erfolge treiben, den Arbeiterstand ansiedeln wollen. Wenn zur Zeit noch derjenige, der von Wiederbelebung der "Erbpacht" oder neuen Typen der "Erbzinsgüter" redet, den Verdacht feudaler Bestrebung auf sich lädt, so kommt auf die Namen wenig an. In dem preußischen "Rentengut", das hoffentlich aus der Provinz Posen bald in andere Provinzen übertragen wird, ist der entscheidende Gedanke unter Schonung aller Vorurtheile in geeigneter Gestalt zum Segen des Ansiedlungswerkes voll verwirklicht.

Nur im Vorübergehen sei erwähnt, wie die romanistische Heraushebung des Eigenthums aus der Reihe der übrigen Rechte zugleich den Sachbegriff mit kulturfeindlichem Erfolge atomistische und materialistisch verunstaltet. Atomistische, indem nur Eigenthum an Sachindividuen anerkannt wird, während wir eine Rechtsordnung brauchen, welche Gessamtsachen, Hauptsachen mit Zubehör und zweckbestimmte Sondervermögen als in sich geschlossene objektive Einheiten und als unmittelbare Gegenstände von Rechtsverhältnissen gelten läßt. Materialistische, indem der Begriff der unkörperlichen Sache wegfällt, hiermit aber die Rechte ohne grobsinnliches Substrat verkümmert, die Immaterialgüterrechte aus geistiger Schöpfung (das "geistige Eigenthum") womöglich unter die singulären und nur durch den Priviligienbegriff zu rettenden Gebilden verwiesen werden. 
On the other front, our private law may not simply repudiate the compromise reached by German law between rights over other people's things and property. Divided property, though it has fulfilled its mission in world history no less because it is declared to be "logically impossible," in its old form has certainly become outdated. It is just that we cannot do without related structures, so long as we elevate new classes of people to their own occupation of land and nurture settlement, for inner colonization with lasting success to house the working classes. If today those who still speak of reviving "inherited leaseholds" or a new type of "inherited rent" invite the suspicion of seeking a return to feudalism, little turns upon a name. In the Prussian "pension property," which will hopefully soon be extended from the province of Poznan to other provinces, the determinative idea has been fully realized-a blessing for the settlement institutions-despite all the prejudices.

It must be mentioned, only in passing, how the Romanistic elevation of property from the sum of other rights atomistically and materialistically corrupts the legal concept of "a thing" in a way that is culturally unfavorable. Atomistic, in the sense that property is only recognized in individual things, while we need a legal framework that recognizes whole things, main things with accessory and purpose-oriented special assets as own legal entities which can all be unintermediated objects of legal relationships. Materialistic, in the sense that the concept of intangible things ceases to exist, thereby diminishing rights without a tangible substratum, leading to immaterial rights to intellectual creations-or "intellectual property"-being sidelined to the singular legal concepts, with the only chance of salvation via the concept of legal privilege. 
Das Privatrecht teilt den Individuen nicht bloß Befugnisse und Pflichten zu, sondern gewährt ihnen auch Gestaltungsfreiheit bei deren Begründung, Veränderung und Aufhebung. In Erfüllung seiner nächsten und vornehmsten Aufgabe, den einzelnen eine Sphäre der äußeren Freiheit behufs Verfolgung der Zwecke des Einzeldaseins zu sichern, erkennt es den individuellen Willen als schöpferische Kraft an. Allein so gewiß es ist, daß eine Privatrechtsordnung, welche den freien Willen entthronte, ihrem heiligsten Berufe untreu würde, so selbstverständlich ist es auch, daß kein Privatrecht, das nicht das soziale Chaos heraufbeschwören will, sich der Aufgabe entziehen kann, dem freien Spiel der Einzelwillen in der Erzeugung von Rechtsverhältnissen Schranken zu setzen. Dies gilt nicht nur, wie niemand je bezweifelt hat, im Sachenrecht und im Personenrecht, sondern es gilt auch auf demjenigen Rechtsgebiet, das vor allem den Tummelplatz rechtsschöpferischer Willenstat bildet, - auf dem Gebiete des Obligationsrechtes. ${ }^{67}$

Wenn das moderne Recht hier den Grundsatz der Vertragsfreiheit durchführt, so kann doch auch hier nicht willkürliche, sondern nur vernünftige Freiheit gemeint sein: Freiheit, die kraft ihrer sittlichen Zweckbestimmung ihr Maß in sich trägt, Freiheit, die zugleich Gebundenheit ist. Schrankenlose Vertragsfreiheit zerstört sich selbst. Eine furchtbare Waffe in der Hand des Starken, ein stumpfes Werkzeug in der Hand des Schwachen, wird sie zum Mittel der Unterdrückung des einen durch den anderen, der schonungslosen Ausbeutung geistiger und wirtschaftlicher Uebermacht.

${ }^{67}$ Der deutsche Entwurf übertreibt den Grundsatz der Vertragsfreiheit im Obligationenrecht, während er ihn im Sachenrecht gewaltsam unterdrückt. 


\subsection{Contracts}

Private law does not merely give individuals powers and duties, but guarantees them freedom to shape the content of their obligations through formation, variation and termination. To fulfil its next and most noble role, to secure the individual's sphere of external freedom to pursue a variety of purposes of existence, it sees individual will as a creative force. Yet it is certain that a private legal order that put free-will on a pedestal would not be true to its most sacred task, and it is also self-evident that no private law, which does not wish to summon social chaos, can abandon its role of setting limits on the free play of individual wills in the creation of legal relationships. This is not only true, as nobody has ever doubted, in property law and in the law of persons, but it is also true in those legal topics which set the level of the playing field for right-creating acts of will,-in the field of the law of obligations. ${ }^{18}$

If a modern legal system introduces the principle of freedom of contract, it can only mean a reasonable freedom, not an arbitrary one: Freedom whose moral purpose requires balance, freedom which sets itself boundaries. Unrestricted freedom of contract destroys itself. A fearsome weapon in the fist of the strong, a blunted tool in the clutch of the weak, it becomes the means of oppression of one by another, the merciless exploitation of intellectual and economic power.

${ }^{18}$ The German Draft exaggerates the principle of freedom of contract in the law of obligations, while suppressing it fiercely in the law of property. 
Das Gesetz, welches mit rücksichtslosem Formalismus aus der freien rechtsgeschäftlichen Bewegung die gewollten oder als gewollt anzunehmenden Folgen entspringen läßt, bringt unter dem Schein einer Friedensordnung das bellum omnium contra omnes in legale Formen. Mehr als je hat heute auch das Privatrecht den Beruf, den Schwachen gegen den Starken, das Wohl der Gesamtheit gegen die Selbstsucht der einzelnen zu schützen. So ist ja längst mit dem Satz, daß Verträge mit unsittlichem Inhalt nicht sind, eine äußerste Grenze gezogen, die mit der Entwicklung des sittlichen Bewußtseins sich immer weiter nach dem Mittelpunkte hin verschoben hat. Indem wir heute die Selbstvernichtung der sittlichen Freiheit, der Persönlichkeit durch die rechtsgeschäftliche Freiheit für unmöglich erklären, versagen wir Verträgen, die einst in voller Blüte standen, jede rechtliche Wirksamkeit. Man denke an Selbstergebung in Knechtschaft oder private Unterthänigkeit, Verzicht auf die Handlungs-fähigkeit, Versprechen der Ehelosigkeit, Haftzusage (Einlager), Verpfändung der Ehre, aber auch übermäßige Einschränkung der Gewerbefreiheit durch Konkurrenzausschlußverträge oder Abtretung des gesamten künftigen Vermögenserwerbs. ${ }^{68}$ Doch ist mit der Garantie der Unveräußerlichkeit der formalen Freiheitsrechte noch wenig getan. Eine Privatrechtsordnung, die ihres sozialen Berufes eingedenk ist, wird zugleich auf einen materiellen Schutz der durch die Vertragsfreiheit gefährdeten Gesellschaftsschichten gegen den Druck wirtschaftlicher Übermacht hinarbeiten müssen.

Ein derartiger Geist soll namentlich das Schuldrecht durchdringen. Der Fortschritt der Kultur hat uns die Abschaffung der Schuldhaft, des letzten Restes der alten Schuldknechtschaft, gebracht.

${ }^{68} \mathrm{Vgl}$. deut Entw. $\$ 350$. 
The law which, with wanton formalism, allows legally significant consequences to spring out of intentional, or presumptively intentional conduct, under the pretense of peaceful order creates a bellum omnium contra omnes in its legal form. ${ }^{*}$ More than ever, it is the task of private law to protect the vulnerable from the strong, the welfare of the whole against the self-interest of the few. For a long time the principle that contracts with an immoral content are void has drawn an outermost boundary, which with the development of the moral consciousness has increasingly converged around a median. As today we proclaim invalid the self-annihilation of moral freedom and personality through freedom to create obligations, we deny contracts which once carried full blooded legal enforcement. One has to think only of selling oneself into slavery or private bondage, relinquishing legal capacity, promises of celibacy, promising to give up one's liberty, mortgaging reputation, but also unreasonable restrictions on business freedom through contracts excluding competition or giving up all the property one would acquire in future.$^{19}$ The guarantee of an inalienable right to formal freedom does precious little. A private law order, which keeps its social vocation in mind, must at the same time be able to work toward the material protection of communities who are endangered by the forces of economic oppression.

Such a spirit should pervade the law of obligations. The progress of culture led us to abolish imprisonment for debt, the last remnant of debt servitude.

\footnotetext{
* Cf. T. Hobbes, LeVIATHAN ch XIII (1651), "a war of all against all."

${ }^{19}$ Cf. German Draft $\$ 350$.
} 
Mehr und mehr hat unser Recht auch Beschränkungen der Vermögenspfändung durchgeführt, damit nicht der dem Gläubiger geliehene Arm des Staates die Quelle selbst verstopfe, aus welcher der Schuldner seine Lebensnotdurft gewinnt. Es bedarf der Weiterentwicklung dieses Gedankens. Nicht minder wichtig aber ist es, daß die Gesetzgebung das Ihrige dazu thue, um von vornherein Verschuldung durch Mißbrauch der Vertragsfreiheit zu verhüten. Von dem Prinzip der Wucherfreiheit sind wir, durch schlimme Erfahrungen belehrt, schon wieder zurückgekommen; wir haben versucht, das alte Wucherverbot, das in der Gestalt willkürlicher fester Zinsmaxima unhaltbar geworden war, in wesenhafterer und freierer Gestalt zu erneuern. Allein wir dürfen nicht, wie das der deutsche Entwurf vorschlägt, unter Vertröstung auf ein besonderes Wuchergesetz aus dem gemeinen Recht alle anderen im Laufe der Jahrhunderte ausgebildeten Schutzmaßregeln gegen übermäßige Ansprüche des Gläubigers, gegen Ausbeutung der Not und des Leichtsinns, gegen unbillige Härte des Schulddruckes ohne Ersatz entfernen. ${ }^{69}$

\footnotetext{
69 Der Entwurf beseitigt unter Anderem: das reichsgesetzlich dem Schuldner garantirte unverzichtbare Kündigungsrecht bei Ueberschreitung des Zinsfußes von sechs Prozent; den Auschluß der Forderung aufgewachsener Zinsen über den Bestand des Kapitales hinaus; das Verbot der Vereinbarung von Zinsen aus rückständigem Zins; die Einschränkungen des Vorabzuges von Zinsen; jede Beschränkung der Höhe der Konventionalstrafe, neben der überdies im Zweifel noch der Ersatz höheren Schadens gefordert werden kann; die lex Anastasiana; die Anfechtung wegen laesio enormis; die Beschränkungen des Verkaufes der Früchte auf dem Halm; den Zinsnachlaß wegen Mißwachses bei der Pacht; das beneficium competentiae, sogar für den Schenker; jede Abstufung der Schadensersatzpflicht nach dem Grade des Verschuldens. Er setzt die Verzugssinsen auch dann, wenn der vereinbarte Zinsfuß niedriger war, auf fünf Prozent, dagegen bei höherem Zinsfuß auf den bisherigen Zinsfuß fest, läßt sie von der Rechtshängigkeit an wieder Zinsen tragen und gestattet daneben die Liquidation eines höheren Interesses. Dem gesetzlichen Pfandrecht des Vermiethers und Verpächters giebt er eine übermäßige Ausdehnung. Dem Miethswucher, dem Mißbrauch der Viehleihe, den Abzahlungsgeschäften und Mobilienleihverträgen tritt er durch seine Bestimmung entgegen und steht rathlos vor der vorausgesehenen Umgehung des Verbotes der Mobiliarpfandrechte ohne Gewahrsam und der lex commissoria durch bedingte Eigenthumsübertragungen.
} 
More and more our law has introduced limits on pledging property, so that the creditor is not assisted by the state in blocking the source by which the debtor secures the necessaries of life. This point requires further elaboration. It is of no small importance that legislatures forbade from the outset the abuse of freedom of contract in relation to indebtedness. We are returning to the principle of freedom from usury, taught through bitter experience; we have tried to revitalize the principle of old prohibitions on usury in a more flexible form, after the form of arbitrarily selected maximum interest rates became untenable. But we simply must not, as the German draft suggests, remove it from the general law with some empty promise of a special usury law, and in the process lose the regulatory protections that have built up over the course of the centuries against immoderate claims of creditors, against exploitation of necessity or carelessness, and against the inequitable hardship of unlimited debt recovery. ${ }^{20}$

\footnotetext{
${ }^{20}$ The Draft excises among other things: The guaranteed right in Empire law to terminate upon an interest rate exceeding 6\%; the exclusion of a demand for interest beyond the value of the capital; the prohibition on agreeing interest on outstanding interest; the limitation of pre-deductions of interest; any limitation on the amount of penalties which can be demanded in addition to compensatory damagers; the lex Anastasiana; rescission on grounds of laesio enormis; the limitation of acquiring the "fruits from the stalk" (a right to land's produce only with possession rather than registration after purchase); the abatement of interest in pledges on grounds of unreasonable growth; beneficium competentiae (the right not to be sued into bankruptcy), even for a donor; every gradation of the duty to compensate according to the grade of fault. It sets the default interest rate at five percent, even when the agreed interest rate is lower, and when the interest rate is higher at the prevailing interest rate, and on Lis alibi pedens (pending a dispute elsewhere) allows next to liquidation a higher rate of interest to be substituted. It gives a disproportionate dimension to the statutory lien of a landlord and renter. Faced with extortionate rents, the misuse of livestock lending, hire purchase, and land lending contracts, its provisions stand helpless against foreseeable circumvention of the prohibition on chattel mortgages without guarantee and lex commissoria (acceleration clause, requiring payment on default of mortgage repayments) through conditional property transfers.
} 
Wir dürfen nicht, wie der deutsche Entwurf beabsichtigt, alle oder doch fast alle Garantien vor übereilter und unüberlegter Bindung beseitigen, die in Formvorschriften für besonders gefährliche Rechtsgeschäfte gegeben sind. ${ }^{70}$ Wir dürfen nicht, wie dies wiederum der deutsche Entwurf plant, neben der wahrlich hinreichend bedenklichen allgemeinen Wechselfähigkeit in den gewöhnlichen bürgerlichen Verkehr noch weitere handelsrechtliche Formalgeschäfte, abstrakte Schuldversprechen und Anweisungsaccepte beliebigen Inhalts in einfacher Schriftform, einführen und mit unbedingt verpflichtender Kraft ausrüsten. ${ }^{71}$ Ein Schuldrecht, das keine höheren Gesichtspunkte als Verkehrsfreiheit und Verkehrssicherheit kennt, gibt den Geschäftsunerfahrenen dem geriebenen Geschäftsmann, den kleinen Bürger und Bauern dem größeren Unternehmer, den Arbeiter dem Kapitalisten wehrlos in die Hand. ${ }^{72}$

\footnotetext{
70 Der Entwurf nimmt von der grundsätzlich durchgeführten Formfreiheit der obligationenrechtlichen Verträge nicht einmal die Bürgschaft aus, während aller Schutz der Frauen und Minderjährigen hier wie überall wegfallen soll.

${ }^{71} \mathrm{Vgl}$. hierüber meinen Aufsatz in Schmoller's Jahrb. Bd XIII S. 217 ff. - Ueber die durchgängige Trennung der als abstraktes Formalgeschäft ausgestalteten Rechtsübertragung vom Kausalgeschäft vgl. Strohal in Jhering's Jahrb. Bd. XXVII S. 335-462.

72 Gegen den Geist des Schuldrechtes im Entwurfe vgl. auch Bähr in der krit. Vierteljahresschrift Bd. XXX S. 567-568 und Hartmann, das Civilgesetzbuch, das Aequitätsprinzip und die Richterstellung, Arch. f. civ. Pr Bd. LXXIII S. 309407.
} 
We must not eliminate, as the German draft intends, all or virtually all protections against rash and ill-considered obligations, such as those which are found in the formalities provisions for especially dangerous legal acts. ${ }^{21}$ We must not, as the German draft envisages, introduce into civil law transactions additional commercially-binding transactions, abstract debt promises or payment instructions of any chosen content through simple written form and make these legally binding, alongside the highly questionable exchangeability of regular legal transactions that already exists. ${ }^{22} \mathrm{~A}$ law of obligations, whose highest conception is freedom of contract and security of trade, leaves the inexperienced business defenseless against the hardened dealer, the small citizen and farmer defenseless against the big corporation, the worker defenseless against the capitalist. ${ }^{23}$

${ }^{21}$ The draft does not even exempt guarantees from the principle of freedom of form that it implements, meaning that all protection for women and children disappears here just as everywhere.

${ }^{22}$ Cf. on this my essay in Schmoller's Jahrbuch (1889) vol XIII, $217 \mathrm{ff}$. On the ongoing separation of the abstract "formal" transaction of transferring rights from the "causative" transaction. $C f$. Strohal in Jhering's Jahrbuch, vol XXVII, 335-462.

${ }^{23}$ Against the spirit of the law of obligations, cf also Bähr in the critical Vierteljahresschrift, vol XXX, 567-568 and Hartmann, The Civil Code, the Equity Principle and the Position of Judges, Archiv für die civilistische Praxis, vol LXXIII, 309-407. 
Die sozialen Bedenken gegen ein derartiges Recht der Schuldverhältnisse steigern sich unermeßlich, sobald dasselbe nicht bloß die in freier Beweglichkeit sich knüpfenden und lösenden Einzel-beziehungen des Verkehrs beherrschen will, sondern auch auf die vertragsmäßig begründeten Verhältnisse dauernder Bindung angewandt werden soll. Hier greift in Wahrheit das Obligationsrecht teils in das Sachenrecht, teils in das Personenrecht über. In ersterer Hinsicht darf, wie schon erwähnt wurde, der sachenrechtliche Keim in der Obligation nicht einer sauberen Trennung zu Liebe erstickt werden. Was aber die personenrechtlichen Bezüge angeht, so muß ein gesundes Privatrecht überall da, wo die Persönlichkeit selbst von der vertragsmäßigen Bindung ergriffen wird, den Begriff der Persönlichkeit in das Zentrum stellen. Das gilt in erster Linie für die Regelung des Dienstvertrages, sobald derselbe nicht bloß eine flüchtige Berührung durch einzelne Dienstleistungen erzeugt, sondern den ganzen Menschen einem Zweckzusammenhange einordnet und einem Lebensberufe zuteilt. Es ist undenkbar, daß wir auf die Dauer bei dem im römischen Sklavenrecht wurzelnden Schema der nach dem Muster der Sachmiete geformten Dienstmiete stehenbleiben! Mit dem vertragsmäßigen Eintritt in die Hausgemeinschaft beginnt das Familienrecht, mit dem Eintritt in ein geschäftliches Unternehmen das gewerbliche Sozialrecht gebieterisch zu walten. Doch davon nachher!

Hier sei zunächst der Blick auf das Willensdogma zurückgewandt, um mit einigen Worten die Kehrseite der rechtsschöpferischen Kraft des Einzelwillens zu beleuchten. Im innersten Wesen des Privatrechts ist es angelegt, daß nicht blos der legitime rechtsgeschäftliche Wille die gewollte Rechtswirkung hervorbringt, sondern auch der schuldhafte rechts-verletzende Wille ungewollte Rechtsverhältnisse schafft. 
The social objections to such a law of obligations are raised immeasurably as soon as such obligations aim, not merely to regulate freely negotiable and terminable trade relations, but also are applied to relations that begin in contract but last over a period of time. In reality, here the law of obligations spills over, partly into the law of property and partly into the law of persons. The latter view, mentioned above, could not permit the proprietary essence of these obligations to smother its clean segregation. But where the law of personal relations is concerned, a robust private law must place the concept of personality at the center of everything. This is especially the case for the regulation of employment contracts, as soon it produces more than a fleeting provision of one-off service, and instead subordinates the person to the purpose of the association and determines one's livelihood. It is unthinkable that we continue to adhere to the scheme of renting things that originated in Roman slave law for the hire of service! With the contractual entry into the home life family law begins to govern, and with the entry into a business undertaking the enterprise element of social law begins to govern. We return to this soon!

\subsection{Wrongs}

But now, we must return to the dogma of the will, and say a few words about the other side of the power to create obligations with an individual will. The innermost essence of private law is concerned, not just with facilitating the legitimate juridical act of will that produces a desired legal result, but also with the will that creates undesired liabilities by infringing the rights of others. 
Die privatrechtliche Schadenersatzverbindlichkeit aus Delikt ist ein Kerngedanke des Rechts! Allein wiederum ist es eine romanistisch-individualistische Verirrung, eine Verkennung der sozialen Aufgabe des Privatrechts, wenn die gesammte Ordnung des Schadenersatzrechtes auf den Deliktsbegriff gebaut werden soll. ${ }^{73}$ Wir können den germanischen Grundsatz der Schadenshaftung aus bloßer Verursachung nicht entbehren. Mag den Urheber der Rechtsverletzung ein eigentliches Verschulden nicht treffen, so ist doch der Geschädigte noch unschuldiger. Die ausgleichende Gerechtigkeit fordert, soweit dies thunlich ist und nicht zu unbilliger Härte auf der Gegenseite führt, eine Überwälzung der Folgen. Darum soll auch der Zurechnungsfähige, der Wahnsinnige, der Trunkene, das Kind den angerichteten Schaden aus seinem Vermögen ersetzen, sofern ihm nur hierdurch die Mittel standesgemäßen Unterhaltes nicht entzogen werden. Und darum soll vor Allem der Eigenthümer einer Sache, eines Thieres, eines Betriebes für den Schaden einstehen, der durch die besondere Gefährlichkeit eines derartigen Bestizthumes Anderen erwächst. Es giebt keine gesellschaftswidrigeren Gedanken, als daß es gestattet sein soll, alle Vortheile aus einem die Mitmenschen gefährdenden Eigenthum zu genießen, ohne das entsprechende Risiko zu tragen. ${ }^{74}$

\footnotetext{
${ }^{73}$ VgI Mataja's angeführte Schrift und dessen Kritik des Entwurfes im Archiv für bürgerl. Recht Bd. I S. 267 ff; meinen Aufsatz in Schmoller's Jahrb. Bd. XIII S. $247 \mathrm{ff}$.

${ }^{74}$ Der deutsche Entwurf weiß von diesem Allen nichts; er bricht mit uraltem arischem Recht hinsichtlich der Haftung für Thiere, gründet die Haftung aus Gebäudeeinsturz lediglich auf Verschulden und kennt selbst eine Vermuthung für Verschulden nur in einem einzigen Fall (beim effusum vel dejectum). Moderne Spezialgesetze jedoch sind einsichtiger. - Nur angedeutet sei hier, daß auch die Haftung aus rechtsgeschäftlicher Verursachung durch irrthümliche oder scherzhafte Erklärung und die Haftung des falsus procurator sich aus dem gleichen Gedanken rechtfertigt (vgl. meinen Aufsatz a. a. O. Bd. XII S. 1252 u. 1255); daß selbst die Entschädigungspflicht aus Zwangsenteignung hier wurzelt; daß die Entschädigung unschuldig Verurtheilter oder Verhafteter von hier aus sich als Rechtspflicht des Staates ergiebt (vgl. meine "Genossenschaftstheorie“ u.s.w. S. 807 ff.).
} 
The private law obligation to pay compensation for wrongs is one of the core ideas of the law. Yet it is a romantic, individualistic misconception, a misjudgment of the social role of private law, when the whole order of compensation is built upon wrongs as a concept. ${ }^{24}$ We cannot do without the Germanic principle of strict liability for damage based upon pure causation. Even though the commissioner of the violation of a legal right may not be at fault, the victim of the wrong is always less at fault. Distributive justice demands that, so long as it is possible and does not create iniquitous hardship to the other, the consequences are transferred. This is why the party who can bear the costs must do so for the insane, the drunk, and the child when those parties are not in a position to pay. And this is why above all, the owner of a thing, an animal, and a business, should stand up for damage that is caused by the particular danger that such ownership risks. There is no greater anti-social idea than that which permits all the advantages to be enjoyed from property that endangers fellow people, without bearing the corresponding risks. ${ }^{25}$

${ }^{24} \mathrm{Cf}$. Mataja quoted work and its criticism of the draft in the Archiv für bürgerliches Recht, vol I, $267 \mathrm{ff}$; my essay in Schmoller's Jahrbuch (1889) vol XIII, $\underline{247 \mathrm{ff}}$.

${ }^{25}$ The German draft recognizes none of this. It breaks from the ancient Aryan legal liability for animals, bases liability for buildings collapsing solely on fault, and acknowledges only a presumption of fault in one single case (for effusum vel dejectum - dangerous escapes). Yet specialised modern Acts are more insightful. - To mention briefly, that liability for causing a transaction through mistaken or mischievous representations and the liability of an unauthorized agent are justified by the same idea. (Cf. my essay, cited above, vol XII, 1252 and 1255); that the obligation to pay compensation for expropriation is rooted here; that compensation of people who were innocent but convicted or imprisoned results from a legal duty of the state ( $C f$. my Genossenschaftstheorie, etc., $807 \mathrm{ff}$.). 
Wir bedürfen aber weiter einer Haftung für fremdes Verschulden: nicht blos in Vertragsverhältnissen, sobald sich Jemand Anderer als Werkzeuge bedient, sondern darüber hinaus in allen Fällen, in denen ein Menschenverband als eine durch ein Haupt dargestellte Einheit, hinter welcher die einzelnen eingegliederten Individuen verschwinden, in die Außenwelt tritt. Die Haftung des Hausherrn für die Hausangehörigen, die Haftung des Geschäftsherrn für seine Leute ist keine normale Durchbrechung der Rechtsidee, sondern ein Postulat sozialer Gerechtig-keit, dessen Erfüllung in sorgfältig erwogenen und abgemessenen Grenzen eine wichtige Aufgabe des Privatrechts der Zukunft bildet. ${ }^{75}$

Bisher sprach ich nur von der Aufgabe des Privatrechts auf dem Gebiete des reinen Vermögensrechtes. Es giebt aber keinen gefährlicheren Irrtum, als die weitverbreitete Anschauung, daß die Aufgabe des Privatrechts im Vermögensrecht beschlossen sei. Alles Vermögen ist nur um der Person willen da, und vor und über jeder vermögensrechtlichen Beziehung steht das Recht der Persönlichkeit. Auch das Privatrecht hat mit den ihm zu Gebote stehenden Mitteln in erster Linie die Persönlichkeit des einzelnen Menschen zu gewährleisten und zu schützen, die Persönlichkeitsrechte (Rechte an der eigenen Person) in ihrer allgemeinen und überall gleichen Erscheinung, in ihrer durch die Zugehörigkeit zu einer bestimmten Personenklasse bedingten oder sonst besonderen Ausprägung und in ihrer individuell erarbeiteten oder sonst erlangten Entfaltung anzuerkennen und zu begrenzen, an ihre Verletzung neben den etwaigen strafrechtlichen Folgen civilrechtliche Verbindlichkeiten zu Wieder-herstellung und Ausgleich zu knüpfen. ${ }^{76}$

\footnotetext{
${ }^{75}$ Der deutsche Entwurf ordnet angemessen die Haftung für Andere in Vertragsverhältnissen, erkennt aber darüber hinaus nur eine Haftung der Gastwirthe für ihre Leute an. Alles Andere bleibt Sonderrecht.

${ }^{76} \mathrm{Vgl}$. die treffenden Bemerkungen von Liszt's, die Grenzlinien zwischen Privatrecht und Strafrecht u.s.w. (Heft 5 der Beiträge zur Erläut. u. Beurth. des Entw. v. Bekker u. Fischer) S. 5 ff.
} 
But we also need liability for other people's actions: Not simply through contractual relationships, where someone else serves as a working instrument, but also in all cases where a human enterprise, which functions as a unity under one direction and behind which the various individuals withdraw, steps into the outside world. Liability of management for those who are managed, and liability of the business for its people, is no ordinary breakthrough in legal ideas. It is a postulate of social justice whose fulfilment serves, within carefully balanced and measured boundaries, an important role for the private law of the future. ${ }^{26}$

So far I have been speaking only about the role of private law where it concerns pure property law. But there is no more dangerous error than the widespread view that the role of private law is limited to property. All property exists merely for the sake of the person, and surrounding every proprietary relationship is the right of developing one's personality. ${ }^{*}$ Private law must use the means at its disposal first and foremost to guarantee and protect the personalities of individual people, to both acknowledge and limit the rights of personality (rights of the individual) in their general and equal manifestation, in their condition as being members of a community, with their unique eccentricities, and in their individually acquired or otherwise attained development, to use civil obligations next to criminal sanctions to vindicate rights where they are harmed, and to secure compensation and redress. ${ }^{27}$

${ }^{26}$ The German draft creates a reasonable order for liability for third parties in contractual relations, but only recognizes liability of proprietors for its people. All others fall under specialized regulation.

* Cf. G.W.F. Hegel, Elements OF THE PhILOSOPHy OF RIGHT $§ 41$ (1820), which also formulates this idea, now embodied in the Grundgesetz 1949, Art. 2.

27 Cf. the related remarks from Liszt, The Boundaries Between Private Law and Criminal Law etc. (vol 5 of the contributions to explanations and judgments of Bekker and Fischer) p. $5 \mathrm{ff}$. 
Den grundlegenden Theil unseres Privatrechts müßte ein durchgebildetes Personenrecht bilden. Die romanistische Dogmatik ist weit davon entfernt, dies zu würdigen, und so wenig wie das Pandektensystem hat der deutsche Entwurf für ein Personenrecht Raum. Nur zögernd und nicht ohne Beimischung einer Fiktion werden die obersten Persönlichkeitsrechte, die Rechte auf Leben, Körper, Freiheit, Ehre, überhaupt zu Bestandtheilen der Privatrechtssphäre geprägt, und unvollkommen bleibt ihr Schutz. Andere Persönlichkeitsgüter entbehren völlig des privatrechtlichen Schutzes. Indem ein Anspruch auf Ersatz immateriellen Schadens nur ausnahms-weise gewährt wird, ${ }^{77}$ versagt die Rechtsordnung da, wo ideelle Interessen von oft höherem Kulturwerth als alle Vermögensinteressen gekränkt werden. Noch immer weiß das gemeine Privatrecht die Rechte am Namen und an anderen Persönlichkeitszeichen, die das Handels- und Gewerberecht im Firmen- und Markenrecht angemessen entwickelt hat, nicht zu Ausdruck und Geltung zu bringen. Und jene im Recht der Persönlichkeit wurzelnden, jedoch zugleich einen vermögensrechtlichen Inhalt entfaltenden Rechte, die als Rechte aus geistiger Schöpfung, als Urheberrecht und Erfinderrecht, dem Individuum und der Kultur eine neue Machtquelle erschlossen haben, werden wenigstens aus dem "reinen" Privatrecht und seinem Horizont verbannt!

77 Ueber die Stellung des deutschen Entwurfs zu dieser Frage vgl. meinen Aufsatz in Schmoller's Jahrb. Bd. XIII S. $194 \mathrm{ff}$. 
The most fundamental element of our private law must be a comprehensive law of persons. Roman dogma is far from capable of appreciating this, and the German draft has as little room for a law of persons as the Pandectian system. Only with hesitation, and not without mixing with fiction, did the highest rights of personality - the right to life, body, freedom, and honor-become part of the private law sphere, and their protection remains incomplete. Other interests in personality have been wholly abandoned by private law's protective scope. Insofar as a claim to compensation for intangible harm is protected only as an exception, ${ }^{28}$ the legal order fails dismally, precisely because interests in ideas are often held to have higher cultural worth than proprietary interests. In its coarse simplicity, private law has still not given expression and effect to the right to one's name, or other personality symbols, which have sensibly developed in commercial, business and trademark law. And those rights, with their roots in the law of personality, but which also have a proprietary content, and which like rights of intellectual creation such as copyright and patents, have opened up a new source of power, will be banished from the "pure" law of property and beyond its horizons.

${ }^{28}$ On the position of the German draft on this question, Cf. my essay in Schmoller's Jahrbook (1889) vol XIII, $194 \mathrm{ff}$. 
Das Privatrecht befaßt sich aber nicht blos mit der für sich stehenden Einzelpersönlichkeit und den ihre Besonderheit intakt lassenden Beziehungen zur Außenwelt, sondern umspannt zugleich dauernde personenrechtliche Verbindungen, in welchen das Individuum mit einem Theil seines Wesens aufgeht. Und schärfer noch trennen sich hier römische und germanische Rechtsanschauung, individualistische und soziale Ordnung!

Privatrecht ist das gesammte Familienrecht. ${ }^{78}$ Das Familienrecht aber kann seine große soziale Aufgabe, die Erhaltung und Festigung der Grundeinheiten des gesellschaftlichen Körpers, nimmermehr erfüllen, wenn es nach romanistischem Schema auf die Souveränität des Individuums gebaut, in gesonderte Rechte an fremder Person und mechanische angeknüpfte Sachenrechte und Schuldverhältnisse auseinandergerissen, als bloßes verwickelteres Individualrecht und nicht zugleich als Keimzelle alles Sozialrechts ausgestaltet wird. Ein solches Familienrecht bietet der deutschen Entwurf. Wir aber brauchen ein Familienrecht, das im Geiste des deutschen Rechts von der Familie ausgeht, aus dem centralen Begriff ihrer organischen Einheit die persönlichen Rechte und Pflichten von Haupt und Gliedern ableitet und bemißt, die vermögensrechtlichen Beziehungen zwischen den Angehörigen der Familie als Ausflüsse der personenrechtlichen Verbindung zu voller Eigenart ausprägt.

\footnotetext{
78 Folgerichtig müßte freilich das romanistische Denken dahin gelangen, nur das Familiengüterrecht dem Privatrecht, dagegen das persönliche Familienrecht dem öffentlichen Recht zuzutheilen. Allein diese Konsequenz, die Sohm, Institutionen (3. Aufl.) S. 94, wirklich zieht, zeigt nur die Unhaltbarkeit der zu Grunde liegenden Vordersätze.
} 


\subsection{Families and Inheritance}

Private law is not merely concerned with the individual personality for its own sake. It does not leave the relationship with the outside world untouched, but also encompasses rights of personality that last over a period of time, into which the individual merges part of his existence. Here the Roman and the Germanic conceptions of the law divide even more sharply, as individualistic and social orders.

The whole of family law is private law. ${ }^{29}$ But family law can never fulfill its great social role, the preservation and consolidation of the elements of the communal body, if it builds upon the romantic scheme of the sovereignty of the individual, if torn apart into special rights in other people and mechanistically connected property rights and obligations, if it is formed as a twisted individual law and not the nucleus of all social rights. Such a family law is what the German draft offers. Yet we need a family law, which starts in the spirit of German rights of the family, which derives and is measured using the central concept of organizational unity of personal rights and duties, of the whole and members, and which expresses proprietary relations between family members as flowing from personal connections that are unique.

\footnotetext{
${ }^{29}$ Logically, it must surely follow from the Roman perspective that only family property law is private law, while personal family law divides into public law. This very consequence, which Sohm, Institutions 94 (3rd ed.), actually draws, shows the unsunstainability of this underlying precept.
} 
Unser Eherecht, einschließlich des ehelichen Güterrechts, soll den Gedanken der Einheit und Gemeinsamkeit zu Grunde legen, so daß unter Vorbehalt von Sonderrechten jedes Theiles im ehelichen Gemeinschafts-bereiche das zur Einheit verschmolzene Ehepaar herrscht, dargestellt durch den Mann als vertretendes und leitendes Haupt, durch die Frau als mitvertretende und mitleitende Herrin des Hauswesens, durch beide Gatten zusammen bei tief eingreifender Verfügung. Mit den drei großen germanischen Rechtsgedanken des ehemännlichen Mundiums, der eheweiblichen Schlüsselgewalt und der ehelichen gesammten Hand sollen wir bei allem Wandeln und Formen nicht brechen. Und bei allen Systemen des ehelichen Güterrechts, mit deren verschiedenen Grundtypen wir nicht ohne gewaltthätigen Eingriff in tief gewurzeltes Rechtsbewußtsein und volksthümliche Sitte aufräumen können, sollen wir dem Gemeinschafts-gedanken die Ehre geben. ${ }^{79}$ Unser Elternund Kinderrecht soll sich auf die Einheit und Gemeinschaft des Hauses gründen und den innigsten, lebensvollsten, am gewaltigsten fesselnden Verband, der auch heute allen Stürmen zum Trotz den festesten Halt der Gesellschaft bildet, nicht lockern, sondern stärken.

\footnotetext{
${ }^{79}$ Der deutsche Entwurf thut das Gegentheil; sein eheliches Güterrecht und insbesondere sein auf Verdrängung der gütergemeinschaftlichen Ordnungen berechneter "gesetzlicher Güterstand" geht von dem Prinzip der Trennung aus, schafft eine unsägliche Fülle einzelner "Ansprüche" des Gatten gegen den Gatten und scheint einen komplizirten rechtsgeschäftlichen und prozessualen Verkehr zwischen Mann und Frau hervorrufen zu wollen.
} 
Our law of marriage, including the law of married couples' property, should be founded on the idea of unity and commonality, so that, with the proviso of special rights belonging to each party in the "marriage community," the married couple governs as an entity. This is characterized by the man as the representing and directing part and the woman as the corepresenting and co-directing part of the household, though in the case of substantial proprietary transactions both must act together. We should not, through legal reforms, break with the three great German legal concepts of paternal protection, of the maternal power to bind the other to obligations necessary to fulfil the requirements of the family, and of the concept of joint spousal ownership. And in every system of married persons' property, which we cannot eliminate without violent interference with deeply embedded legal consciousness, we should honor the communal ideal. ${ }^{30}$ Our parental and child law should be based on the unity and community of the household and not weaken but strengthen the most inner, most full of life, and strongly anchored association, which even today weathers all storms and still constitutes the securest foundation of our society.

\footnotetext{
${ }^{30}$ The German draft does the opposite; its marital property law, and especially its "statutory matrimonial regime," calculated to displace the communal marital order, starts from the principle of separation, creates an unspeakable mass of individual "claims" for spouse against spouse, and seems to positively desire complex transactional and litigious intercourse between husband and wife.
} 
Eine kräftige, jedoch mit ernster Pflicht durchsetzte elterliche Gewalt als gemeinschaftliches Elternrecht, unter Mitwirkung der Mutter vom Vater gehandhabt, bei Verhinderung oder Wegfall des Vaters von der Mutter in beschränktester Weise ausgeübt, das etwaige Kindesvermögen mit dem Elternvermögen zum einheitlich benutzten und verwalteten Hausvermögen zusammenfassend, mit der Lösung der Hausgemeinschaft, aber nicht vor ihr endend - das muß der unantastbare Kern unseres Familienrechts bleiben oder von Neuem werden. ${ }^{80}$ Wo der Familienschutz unzureichend ist oder in sein Gegentheil umschlägt, muß ergänzend oder abhelfend die Schutzgewalt des Gemeinwesens über Unmündige und Gebrechliche walten. Starker Attribute, umfassender Zuständigkeit, eingreifender Zwangsmittel bedarf in der heutigen so mannigfaltig zersetzten Gesellschaft die staatliche Obervormundschaft. Niemals aber soll sie die Familie enthronen, niemals ohne Noth die heiligen uralten Rechte von Vater und Mutter verkümmern. Und wo an Stelle des geborenen Muntwalts der Vormund tritt, da sollen wir bei aller öffentlichen Fürsorge und Aufsicht doch immer eingedenk bleiben, daß die Vormundschaft als Ersatz der naturgegebenen Schutzgewalt ihre tiefsten Wurzeln und ihre sicherste Gewähr in den Zusammenhängen des Familienrechts hat.

Auf dem Familienrecht beruht nach germanischer Anschauung das Erbrecht, während die romanistische Auffassung alles Erbrecht auf den über den Tod hinauswirkenden erklärten oder vermutheten Willen des Individuums gründet.

\footnotetext{
${ }^{80}$ Der deutsche Entwurf kennt keine Hausgemeinschaft; selbst die "fortgesetzte Gütergemeinschaft" löst er von dem Gedanken der Hausgemeinschaft ab. Seine "elterliche Gewalt" ist einseitiges Recht des Vaters oder der Mutter, in beiden Fällen gleich bemessen. Die elterliche Nutznießung und Verwaltung reißt er in wesentlichen Stücken, die elterliche Unterhaltspflicht völlig von der elterlichen Gewalt los. Inhaltlich gestaltet er diese Gewalt von Gotten Gnaden nach dem Muster der staatlich übertragenen Altersvormundschaft aus, das germanische Mundium mit moderner Vormundschaft verwechselnd. Und folgerichtig läßt er sie mit der Großjährigkeit enden, so daß sie bei früherer Heirath des Kindes fortbesteht, dagegen über das im Hause verbleibende großjährige Kind wegfällt.
} 
Strong and stern parental power, as a communal parental law, implemented by the father and influenced by the mother-in the father's absence in the most limited way possible-in a way that combines the child's and the parent's assets to a separately used and administered "house-asset," that ends with the termination of the household, but not before. That must remain the inviolable core of our family law, or become the new one. ${ }^{31}$ Where family protection is insufficient, or it changes suddenly into its opposite, social protection must complement or remedy the deficiency and administer the people who lack capacity and invalids. Strong attributes, comprehensive competence, interventionist means, all require state oversight in todays multifaceted and disaggregated society. But it should never dethrone the family, and never without an emergency let the holy and age-old rights of fathers and mothers go to waste. And where the state stands as a guardian in place of the natural guardians, there we should remain of one view for all public care and oversight, that the guardianship, as a replacement for natural protectors, has the deepest roots and the safest guarantee in the togetherness of family law.

The law of inheritance according to the Germanic view is built upon family law, whilst the Romanistic conception of all inheritance law is based upon the express or supposed will of the individual speaking after death.

\footnotetext{
${ }^{31}$ The German draft does not recognize the home community; it even removes the "continuing communal property" from the idea of the home community. Its "parental authority" is a unilateral right of the father or mother, assessed the same in both cases. It tears the parental usufruct and management in its essential parts, the parental duty of maintainence from parental authority. It designs the content of this power by the divinity of God according to the model of the state conferred old-age guardianship, confusing the germanic Mundium with modern guardianship. And consequently, it lets authority end with age, so that it persists with a previous marriage of a child, but falls away with the eldest child remaining in the house.
} 
Wir haben die römische Testierfreiheit in unser Bewußtsein und zum Theil in unsere Sitten aufgenommen und können mit ihr nicht brechen. Wollen wir aber nicht die ganze Zukunft des Erbrechts in Frage stellen, so dürfen wir es nimmermehr vom individuellen Willen her aufbauen! Immer vielmehr müssen wir an dem im Volksbewußtsein noch ungebrochenen nationalen Grundgedanken festhalten, daß die auf personenrechtliche Zusammenhänge gegründete gesetzliche Erbfolge das Primäre ist, die dem Einzelwillen eingeräumte Verfügungsmacht aber nur die Bestimmung hat, die gesetzliche Regel konkret auszugestalten und vorbehaltlich gewisser unüberschreitbarer Schranken in besonderen Fällen durch eine den Umständen nach geeignetere Anordnung zu ersetzen. Nur in der Verwirklichung der im natürlichen Bau der Familie angelegten Geschlechterfolge, in dem Eintritt der kraft der Gliederung des gesellschaftlichen Körpers hierzu nächstberufenen Individuen in die leer gewordene Stelle liegt die unvergleichlich werthvolle soziale Funktion, liegt die unvergängliche innere Berechtigung des Erbrechts. Von hier aus werden wir auch das rechte Verständnis für das Bedürfniß einer Sondererbfolge in den Grundbesitz und die Fähigkeit zu deren angemessener Ausgestaltung in lebensfähigen Rechtsinstituten gewinnen. Zugleich aber werden wir die Überspannung des Erbrechts durch Erstreckung in das Unbegrenzte abschütteln und jenseits der Verwand-schaftsgrade, innerhalb deren erfahrungsgemäß der Familienzusammen-hang seine organische Kraft erschöpft, den Heimfall des Vermögens an die Allgemeinheit eintreten lassen. ${ }^{81}$

Neben dem naturgegebenen Familienbande hat das Privatrecht auch gekorne Verbindungen zu normiren, deren Wesen es nur gerecht werden kann, wenn es sie als personenrechtliche Gebilde begreift und ausgestaltet.

${ }^{81} \mathrm{Im}$ deutschen Entwurf ist auch das Erbrecht durchweg romanistisch und individualistisch fundamentirt, die Verfügung von Todeswegen vorangestellt, der Grundsatz der Universalsuccession (besonders durch Abschaffung des Vindikationslegats) übertrieben, das Pflichttheilsrecht zu einer Geldforderung abgeschwächt, die Verwandtenerbfolge in das Unbegrenzte ausgedehnt, die deutschrechtliche Sondererbfolge ausgewiesen. 
We have taken the Roman concept of testamentary freedom into our consciousness and partly into our spirit, and cannot break with it. But if we do not want the whole future of inheritance law to be put in question, we may no longer build upon individual wills. Increasingly we must hold on to the unbroken notion that exists in the people's consciousness, that the statutory default line of succession, based on personal legal relations has priority and that individual wills can only make a determination to concretize this statutory default line of succession or to replace it in appropriate circumstances within certain uncrossable boundaries. Only in the realization of the natural construction of the family's line of inheritance, in the entrance of the next individual in line into the empty place by virtue of the social body, lies the incomparably valuable social function, and the eternal inner justification, of the right to inheritance. From this we will gain a proper understanding of the necessity for a special legal framework for succession in estates, and the possibility to establish these in viable legal institutions. But at the same time, we will shake off the overreach of inheritance law, which is stretched beyond its limits, and let wealth fall back to society beyond relative-lines, where family-relations have typically lost their organic power. ${ }^{32}$

Alongside natural family associations, private law must also provide for created connections, whose existence can only be just if they are constructed and understood as legal entities.

\footnotetext{
${ }^{32}$ In the German draft, inheritence law is also Romanist and individualistic throughout, based around the will and testament, exaggerating the principle of universal succession (especially by abolishing the right to claim vindication in inheritance), weakening the right to legal portion to a demand for money, extending relatives' inheritance indefinitely, and expelling the German law special inheritance.
} 
Zunächst spielen im heutigen Leben Herrschaftsverbände eine Rolle, die man damit nicht aus der Welt schafft, daß man sie nicht zu sehen vorgiebt. Ein Herrschaftsverband entsteht aus der Erweiterung der Hausgemeinschaft durch das Gesinde und die höhere Hausdienerschaft. Darum reicht hier das nackte Obligationsrecht nicht aus, sondern bedarf der Ergänzung und Umbildung durch familienrechtliche Sätze. Unser Gesinderecht hat glücklicher Weise trotz alles Ansturmes der abstrakten Theorie diesen Gedanken bisher mit ziemlicher Energie bewahrt; gerade deshalb will es der deutsche Entwurf, indem er es in das Landesrecht verweist, aus dem "reinen" Privatrecht verbannen. Die Rechtsverhältnisse der höheren Hausdiener (Erzieher und Erzieherinnen, Gesellschafterinnen usw.) werden heute noch im preußischen Landrecht durch besondere Vorschriften im Familienrecht geordnet; der deutsche Entwurf will diese wichtige, schutzwürdige und schutzbedürftige Personenklasse lediglich seinen kahlen Sätzen über den Dienstvertrag unterwerfen. Vor Allem jedoch sind es in Wahrheit kleinere und größere, zum Theil ins Riesenhafte ausgewachsene privatrechtliche Herrschaftsverbände, welche in der Form des geschäftlichen Unternehmens heute als die eigentlichen Träger unseres wirthschaftlichen Lebens erscheinen. Wozu soll es nützen, diese klar am Tage liegende Thatsache abzuleugnen? Was wird denn erreicht mit der von unserem Rechtssystem immer noch festgehaltenen Fiktion, daß hier nichts weiter vorliegt, als eine Summe obligationenrechtlicher Einzelbeziehungen zwischen freien und gleichen Individuen? Wohl bleibt es, so viel oder so wenig Spielraum die zwingende Macht der Verhältnisse thatsächlich dem freien Entschlusse lassen mag, juristisch stets der freie Vertrag, der die Einzelnen bindet und entbindet. Aber dieser Vertrag erzeugt nicht blos ein einzelnes Schuldverhältniß, sondern gliedert die Persönlichkeit selbst einem wirtschaftlichen Organismus ein. 


\subsection{Enterprise Associations}

To begin, in life today internally dominated associations (Herrschaftsverbände) play a role that one cannot sideline or pretend not to see. An internally dominated association arises from the extension of the concept of a home community with servants and a hierarchy of domestic workers. The naked law of obligations is not sufficient here, but requires the supplementation and transformation through family law principles. Fortunately our law of servants has, despite the attack of abstract theory, preserved these ideas with considerable energy; precisely because of this the German draft, insofar as it refers to land law, wishes to banish them from "pure" private law. The legal relationships of senior domestic workers (the educators, partners, etc.) are still found today in special rules of Prussian land law; the German draft seeks to subjugate these important classes of persons, who are worthy of protection and necessary to protect, to bleak provisions on the contract of service. Above all, this is true for small or great, and partly for enormous private internally dominated associations, where the form of business undertaking has emerged today as the standard bearer of our economic life. What would it achieve to disown this fact, which is as clear as day? What would be achieved with the fiction that our legal system still holds onto, that here nothing more exists other than the sum of individual legal obligations between free and equal individuals? In law it is always the free contract which will bind or release the individual, with as much or as little room as the dominant party wishes to allow for free decision. But this contract does not merely produce a relationship of obligation, rather it composes the personality itself of an economic organism. 
Als ein monarchisch organisirtes Ganzes, dessen alleiniger Träger der Unternehmer ist und dem Angestellte und Arbeiter als dienende Glieder angehören, tritt ein solcher Verband nach innen und außen auf. Unser gesammtes modernes Handels- und Gewerberecht hat mehr und mehr eine Fülle von Folgesätzen entwickelt, denen die unausgesprochene Voraussetzung des Daseins einer Verbandseinheit zu Grunde liegt. Hier wurzelt die Verantwortlichkeit des Geschäftsherrn nach außen (Haftpflicht), hier die unter öffentlicher Kontrolle gestellte und durch staatlichen Zwang verwirklichte rechtliche Ausgestaltung eines sittlichen Gehaltes des Verhältnisses nach innen (Garantien gegen Verkümmerung der Persönlichkeit, gegen Ausbeutung des Schwächeren und gegen Auflösung der Familie, Verpflichtung zu Schutz und positiver Fürsorge). Der großartige, auch in Oesterreich glücklich aufgenommene Versuch der deutschen Reichsgesetzgebung, durch eine allgemeine Organisation die arbeitenden Klassen gegen Noth aus Krankheit, Betriebsunfällen, Alter und Invalidität zu sichern, würde haltlos in der Luft schweben, wenn er mit unverbundenen Individuen und nicht mit vorgefundenen Verbands-einheiten rechnete. Alle ferner sozialpolitische Gesetzgebung wird den Gedanken, daß das moderne geschäftliche Unternehmen eine Form personenrechtlicher Verbindung ist, nur immer klarer herausstellen und immer weiter entfalten können. Löst da wirklich das gemeine Privatrecht seine Aufgabe, wenn es gleich dem Vogel Strauß den Kopf in den Busch steckt und bei dem lügenhaften Schema des streng indivualistischen reinen Obligationenrechts verharrt?

Weiter steigt unser modernes Gesellschafts- und Gemein-schaftsrecht in einer Fülle von Gebilden über die individualistischen Typen der römischen Sozietät und der römischen Kommunion zu Personeneinheit nach innen und außen sich als Trägerin einer Gesammtsphäre bethätigt. 
An association appears internally and externally as if the organizational whole were a monarchy, the sole carrier is the entrepreneur, and the officials and workers belong as serving members. Our entire modern commercial and business law has developed an evergreater mass of provisions, whose unspoken and underlying premise is the existence of unity of association. Here lie the roots of the responsibility of management in external affairs (vicarious liability), and here the legal expression of just relations in internal affairs, made under public control and realized through state compulsion (guarantees against insolvency of the legal person, against exploitation of the weaker party and against the dissolution of the family, an obligation of protection and positive care). The great attempt of the German Empire's legislature, fortunately seen in Austria too, to insure the working classes against emergencies from sickness, accidents, old age and disability through a general organization would drift aimlessly through the air if it had to deal with disorganized individuals and not with established associations. All future socio-political legislation will only establish ever more clearly, and develop ever further, that the modern business undertaking is a form of association in the law of persons. Does the simplistic private law really resolve its role, if it sticks its head in the ground like an ostrich and clings onto the deceitful scheme of a strictly individualistic pure law of obligations?

Our modern company and cooperative law follows the plethora of models of individualistic types of Roman societies and communal associations on the inside, while externally it operates as a carrier for the whole sphere. 
Wieder handelt es sich um lebensvolle germanische Rechtsgedanken, wie sie in der deutschrechtlichen Gesellschaft, die in der Handelsgesellschaft ihren kräftigsten Sproß getrieben hat, und in der deutschrechtlichen Gemeinschaft zur gesammten Hand verkörpert sind. Ein Privatrecht, das seine soziale Aufgabe begreift, wird nicht gleich dem deutschen Entwurf mit Sozietätsobligation und Kommunionsverhältnissen abschließen, sondern die innigeren und festeren Gesellschafts- und Gemeinschafts-formen des nationalen Rechtes in seinen Rahmen aufnehmen und ihrem wahren Wesen gemäß normiren. ${ }^{82}$

Darüber hinaus umspannt das Privatrecht den gesammten Bau und das innere und äußere Leben zahlreicher Verbände, die als voll entwickelte Verbandspersonen ein selbständiges Dasein führen. Denn wenn der Staat gewisse Anstalten und Körperschaften werthet und ganz oder theilweise dem öffentlichen Rechte einverleibt, so weist er die Stiftungen und alle als privatrechtliche Körperschaften behandelten Genossenschaften und Vereine in das Privatrecht. Hier streift das Privatrecht überhaupt den Charakter des Individualrechts ab und geht in Sozialrecht über. Denn hier hat es nicht mehr blos mit verbundenen Individuen, sondern mit Wesen höherer Ordnung zu thun, die als beständige und dauernde Träger einer sozialen Willenseinheit sich der Erfüllung eines eignen Lebenszweckes widmen.

82 Der deutsche Entwurf konstruirt die Gesellschaft ganz im Sinne der römischen societas und eröffnet nur der Erwerbsgesellschaft, falls sie mit solchem Recht nicht leben kann, den Ausweg der Flucht in das Gewand der offenen Handelsgesellschaft; er führt bei der Gemeinschaft - mit einziger Ausnahme der ehelichen Gütergemeinschaft, aber mit Einschluß der Erbengemeinschaft - in voller Strenge das Prinzip der schlechthin getrennten Antheile durch. 
Again, this concerns a vibrant German legal idea, which is embodied in the German company, whose strongest expression is found in the business corporation, and the German law concept of the company-partnership. ${ }^{*}$ A private law which grasps its social role will not shut out social obligations and communal relationships like the German draft does, but will include the trusty and steady company and cooperative forms of national law in its framework, and codify their true essence. ${ }^{33}$

In addition, private law encompasses all the building blocks of the internal and external life of countless associations which lead a fully developed independent existence. This is because, when the state values particular institutions or corporations and wholly or partly merges them into public law, it implicitly places other foundations, and cooperative bodies that are handled by private law, and associations, into private law. Here private law wholly sheds its character of individual rights, and is transformed into social law. Because here it is no longer just to do with interconnected individuals, but with an existence of a higher order, that applies itself as the constant and enduring bearer of a social unity of intention, that seeks the fulfilment of its own life purposes.

\footnotetext{
* The concept of a Gesamthandgemeinschaft has no direct translation: It refers to a group of quasi-corporate partnerships such as the Gesellschaft bürgerlichen Rechts (BGB §§705-740), Gütergemeinschaft (BGB §1419) and the Erbengemeinschaft (BGB §2032).

33 The German draft conceives the company entirely in the sense of a Roman societas and only allows a company which people buy into, if it is unable to survive such a law, a way out of the flight of organizations into the form of the "Open Trading Company;" it introduces in community organizations-with the solitary exception of the marital community, but including the inheritance community-the principle of absolutely separate units with full rigour.
} 
Darum beginnt hier eine ganz neue Reihe spezifischer Rechtsbegriffe und Rechtsverhältnisse, die in den Niederungen des Individualrechts kein Vorbild haben, dagegen inmitten des Privatrechts bereits die Gedankenwelt verwirklichen, aus der das öffentliche Recht sich erhebt. In den Stiftungen springen aus individueller Willensthat bleibende Anstaltsorganismen hervor, die ein in Sozialvermögen übergeleitetes Individualvermögen für gemeinnützige Zwecke verwalten und verwenden. Die Vereine und Genossenschaften lösen sich als Gemeinwesen von den Einzelwesen ab, entfalten Gemeinwillen, Gemeinsinn und Gemeinleben und dienen in unendlicher Mannichfaltigkeit den mit vereinzelter Kraft nicht erreichbaren ideelen und materiellen Zwecken des Menschenlebens. Den sozialen Werth der Assoziation Ihnen ausmalen zu wollen, hieße Eulen nach Athen tragen. Erfüllt aber unser Privatrecht die große Aufgabe, die ihm hier zufällt? In zahlreichen Sondergesetzen für einzelne Körperschaftsgattungen sicherlich! Allein in den grundlegenden Lehren des gemeinen Privatrechts geht immer noch das schattenhafte Gespenst der persona ficta um und verzerrt und zerfetzt den Gedanken des Gemeinwesens, bis nur noch eine individualistische Schablone übrig bleibt: ein künstliches Individuum neben natürlichen Individuen, als willens- und handlungsfähiges Geschöpf wie ein Kind oder Wahnsinniger vertreten, in allen Rechtsverhältnissen nach Art eines beliebigen Dritten den Mitgliedern fremd gegenüberstehend. Und im Zusammenhange hiermit weigert sich das Privatrecht immer noch, ohne besondere Verleihung des Geschenkes dieser fingirten Persönlichkeit Vereinsgebilde, die kraft öffentlichen Rechtes vollkommen rechtmäßig bestehen und handeln, auch im Gebiete des Vermögensrechtes als dasjenige anzuerkennen, was sie sind! 
This is why a whole new catalogue of specific legal concepts and relationships begins here. It has no model in the nether lands of individual rights. Amidst private law, a world of ideas elevates itself out of public law. In foundations, enduring institutional organisms arise from individual acts of will, which administer and use social and individual property for common goals. The clubs and cooperatives detach themselves as common beings from individual beings, with a common sense and common life, and serve the unending, manifold ideals and material purposes of human existence, in a way that cannot be achieved through independent action. To impress the social worth of the association upon you would be as unnecessary as bringing owls to Athens. But will our private law fulfil its great role, which is being closed here? In countless specialized laws, for individual species of corporate body, sure. Yet in the foundational teachings of private law, the shadowy specter of the persona ficta still haunts us, and twists and shreds the idea of a common existence until only an individualist outline is left: An artificial individual next to natural individuals, creatures capable of will and action like children or the insane, in all legal relationships no matter which third party the member interacts with. And in connection with this, private law still declines to confer the power of public law to exist and act with complete legality, without special concession of this fabricated personality of association, and even in the field of ownership rights to acknowledge what they actually are! 
Mit besonderer Schroffheit führt wieder der deutsche Entwurf in seinem dürftigen Körperschaftsrecht das romanistisch-individualistische Dogma durch und erschwert damit die freie Fortentwicklung des genossens-chaftlichen Gestaltungstriebes, dessen Pflege zu den vornehmsten Aufgaben unseres Privatrechts gehört.

Denn in der Gesundheit und Lebenskraft der Zwischengebilde zwischen Individuum und Allgemeinheit beruht die Widerstandsfähigkeit des gesellschaftlichen Körpers gegen innere und äußere Gefahren. Was also das Privatrecht in diesem mehrfach abgestuften Aufstieg von dem für sich stehenden Einzelnen zur organisirten Gemeinschaft leistet, indem es die Trennung der Menschen durch ihre Vereinigung überwindet und zugleich das System der Individualvermögen durch mannichfach abgetönte Formen des kollektiven und genossenschaftlichen Gesammtvermögens ergänzt und berechtigt, dient unmittelbar der sozialen Idee.

Zuletzt reicht der Beruf des Privatrechts auch hinein in die Gebiete des öffentlichen Rechts. Das Privatrecht ergreift die öffentlichrechtlichen Verbandspersonen und den Staat selbst, insoweit sie unter Ablegung ihrer Hoheit in den Bereich der individualrechtlichen Verhältnisse und insbesondere in den Vermögensverkehr eintreten. Und das öffentliche Recht verwebt in seine eignen Bildungen privatrechtliche Elemente, so daß aus Zuständen und Vorgängen des Gemeinlebens öffentlicher Körperschaften und Anstalten und des Staates selbst privatrechtliche Befugnisse und Verbindlichkeiten hervorsprießen. ${ }^{83}$

\footnotetext{
83 Dieser Erscheinung bin ich in meinem Buche über "die Genossenschaftstheorie und die deutsche Rechtsprechung" nachgegangen. Die mit der Mitgliedschaft oder einer Organstellung in einer Gemeinde oder einer anderen öffentlichrechtlichen Körperschaft oder Anstalt verknüpften Sonderrechte und Sonderpflichten bilden eine hierher gehörige Kategorie. Von staatlichen Verhältnissen mögen die vermögensrechtlichen Ansprüche der Beamten, die Entschädigungspflicht aus Zwangsenteignung, die Ersatzpflicht des Staates aus dem Mißbrauch von Hoheitsrechten durch seine Organe angeführt sein. Man denke auch an das Privatfürstenrecht. - Vgl auch die Abhandlung von A. Menzel, Die rechtliche Natur der Unterstützungsansprüche aus den Reichsgesetzen über die Kranken- und Unfallversicherung der Arbeiter, Archiv für bürgerliches Recht I S. 327 ff., der jedenfalls bezüglich der Verweisung dieser Ansprüche in das Privatrecht und der hierüber auf S. 332 gemachten allgemeinen Bemerkungen zuzustimmen ist.
} 
With particular abruptness, in its meagre law of persons the German draft is again driving through the Roman-individualist dogma, and aggravating the free development of cooperative forms, care for which should count as one of the most distinguished roles of our private law.

This is because the health and life of intermediate models, that fall between individuals and the commonality, are based on the community's power to resist internal and external dangers. What private law achieves in this multi-level society, where people's organization overcomes their separation, and the system of individual ownership is simultaneously supplemented and justified by multifaceted forms of collective and cooperative common ownership, directly serves the social ideal.

Lastly, the vocation of private law reaches into the fields of public law. Private law embraces public associations and the state itself, insofar as they act beyond their sovereign powers in the sphere of individual legal relationships, and in particular in the course of trade. And public law is laced through, in its own image, with private law elements, so that out of the circumstances and process of communal life, and from public bodies and institutions and the state itself spring forward private law powers and obligations. ${ }^{34}$

\footnotetext{
${ }^{34}$ I elaborate on this phenomenon in my book on The Theory of Cooperatives and German Jurisprudence. The special rights that attach to membership or belonging in a municipality or another public law corporation or institution constitute a category here. The proprietary claims of officials, the duty of compensation for compulsory purchase, the duty of replacement by the state for misuse of sovereign powers carried out through its organs. One may also think about the private law of Princes. - Cf. also the treatment by A. Menzel, The Legal Nature of the Support Claims in Empire Acts on Sickness and Accident Insurance for Workers, Archiv für bürgerliches Recht, vol I, $327 \mathrm{ff}$., which in any case concurs in connection with the reference of these claims in private law, and the general comments on page 332.
} 
Privatrecht und öffentliches Recht sind eben Kinder Einer Mutter, die zwar ein jedes einen eignen Beruf verfolgen, aber nicht wie feindliche Brüder auseinanderstreben, sondern zuletzt immer wieder sich in der Arbeit am gemeinsamen Werk zusammenfinden.

Nur in flüchtigen Umrissen vermochte ich ein Bild von der sozialen Aufgabe des heutigen Privatrechts zu entwerfen. Groß und schwierig ist das Problem. Dennoch muß es gelöst werden, wenn anders das Erbe unserer Väter nicht verloren gehen soll. Unser Privatrecht wird sozialer sein, oder es wird nicht sein. Wohl mag erst eine ferne Zukunft die Bestätigung bringen. Denn langsam nur vollziehen sich bei aller Kraft und Stetigkeit die aus der Häufung von Millionen kleiner Einzeleffekte entspringenden sozialen Wirkungen des Privatrechts: späte Enkel erst ernten den vollen Segen oder Unsegen eines neuen Familien- oder Erbrechts. Gerade hierin liegt jedoch die ungeheure Verantwortung, die auf der Gegenwart lastet. Alle Kulturvölker haben daran teil. Keines aber trägt zu dieser Stunde so hohen Beruf und so ernste Pflicht, wie das deutsche! Denn das bürgerliche Gesetzbuch des deutschen Reiches soll auf lange hinaus über die Schicksale des germanischen Rechtsgedankens in seiner Urheimath entscheiden. Nicht unmittelbar, m. H.! werden Sie hier im deutschen Oesterreich davon betroffen. Aber wäre es denkbar, daß Ihnen irgend etwas fremd wäre, was die Zukunft deutschen Wesens berüht? 
Private law and public law are ultimately the children of one mother. They certainly each follow their own vocations, but they do not scuffle like quarrelsome brothers, and in the end, time after time, find themselves occupied with a work in common.

\section{Conclusion}

At least in a fleeting outline, I have sought to convey one image of the social role of today's private law. The problem is great and challenging. But it must be solved if the inheritance of our forefathers is not to be lost. Our private law will become more social, or it will be no more. Only the future will tell. Because only gradually do the millions of individual effects accumulate into social results of private law: Future grandchildren will either yield the full blessing, or not, of a new family or inheritance law. Right here lies an awesome responsibility, which burdens the present. All peoples are a part of it. But in this hour none bear such a heavy burden, and have such a serious duty, as the Germans. Because the Civil Code of the German Empire will for many years to come determine the fate of German legal thought in its homeland. You may not, dear gathering, be directly affected here in Germanspeaking Austria. But is it conceivable, that that which affects the future of German existence would not affect you too? 
Die lebhafte Theilnahme, mit der Sie das Gesetzgebungswerk jenseit Ihrer Grenzen verfolgen, beweist das Gegentheil. Sie wissen und empfinden, daß eine deutsche Sache von solcher Tragweite auch Ihre Sache ist. In diesem Sinne darf ich auch Ihnen die Bitte ans Herz legen, mizuwirken an der mühevollen Arbeit, welche noch vollbracht werden muß, auf daß ein volksthümliches, ein deutsches, ein soziales gemeines Privatrecht im deutschen Reiche erstehe. 
The lively participation, with which legislative work has crossed your borders, proves the opposite. You know and feel that a German matter of such importance is your concern too. In this sense, I would also like to request from the heart to participate in this difficult project, which must be completed, so that a communal, a German, and a common social private law develops in the German Empire. 